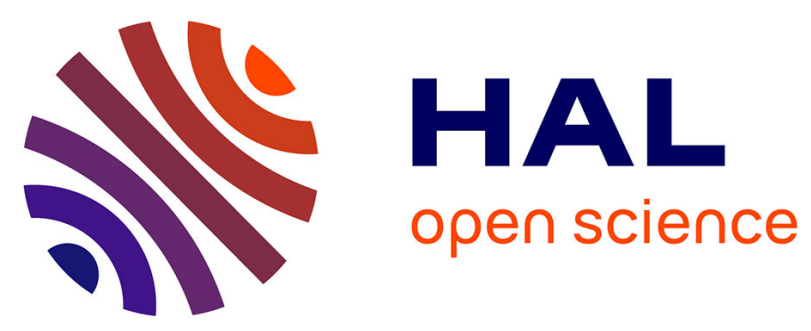

\title{
Highly siderophile and chalcophile element behaviour in abyssal-type and supra-subduction zone mantle: New insights from the New Caledonia ophiolite
}

Arianna Secchiari, Philipp Gleissner, Chunhui Li, Alexey Goncharov, Ralf Milke, Harry Becker, Delphine Bosch, Alessandra Montanini

\section{To cite this version:}

Arianna Secchiari, Philipp Gleissner, Chunhui Li, Alexey Goncharov, Ralf Milke, et al.. Highly siderophile and chalcophile element behaviour in abyssal-type and supra-subduction zone mantle: New insights from the New Caledonia ophiolite. Lithos, 2020, 354-355, pp.105338. 10.1016/j.lithos.2019.105338 . hal-02561845

\section{HAL Id: hal-02561845 \\ https://hal.umontpellier.fr/hal-02561845}

Submitted on 18 Nov 2020

HAL is a multi-disciplinary open access archive for the deposit and dissemination of scientific research documents, whether they are published or not. The documents may come from teaching and research institutions in France or abroad, or from public or private research centers.
L'archive ouverte pluridisciplinaire HAL, est destinée au dépôt et à la diffusion de documents scientifiques de niveau recherche, publiés ou non, émanant des établissements d'enseignement et de recherche français ou étrangers, des laboratoires publics ou privés. 


\title{
Highly siderophile and chalcophile element behaviour in abyssal-type and supra-subduction zone mantle: New insights from the New Caledonia ophiolite
}

\author{
Arianna Secchiari ${ }^{\mathrm{a}, \mathrm{b}}$, Philipp Gleissner ${ }^{\mathrm{a}}$, Chunhui Li ${ }^{\mathrm{c}}$, Alexey Goncharov ${ }^{\mathrm{d}}$, Ralf Milke ${ }^{\mathrm{a}}$, Harry Becker ${ }^{\mathrm{a}}$, \\ Delphine Bosch ${ }^{\mathrm{e}}$, Alessandra Montanini ${ }^{\mathrm{b}, *}$ \\ a Institut für Geologische Wissenschaften, Freie Universität Berlin, Germany \\ ${ }^{\mathrm{b}}$ Department of Chemistry, Life Sciences and Environmental Sustainability, University of Parma, Italy \\ c Department of Geophysics and Planetary Sciences, University of Science and Technology of China, Hefei, China \\ d Department of Geophysics, Saint Petersburg State University, Russia \\ e Géosciences Montpellier, Université de Montpellier, France
}

\section{A B S T R A C T}

The New Caledonia Ophiolite hosts one of the largest obducted mantle sections worldwide, offering a unique opportunity to investigate key mantle processes. The ophiolite comprises refractory harzburgites, locally overlain by mafic-ultramafic cumulates, and minor lherzolites. Previous geochemical studies indicated that the lherzolites are akin to abyssal-type peridotites, while the harzburgites underwent multiple melting episodes in MOR and supra-subduction zone environments, followed by late stage metasomatism.

In this work, Os isotopes, highly siderophile (HSE) and chalcophile element data are reported for the New Caledonia peridotites, in order to constrain the behaviour of these elements in abyssal-type and fore-arc mantle. The variably serpentinised lherzolites ( $\mathrm{LOI}=6.4-10.7 \%$ ) yield slightly subchondritic to suprachondritic initial Os isotopic compositions $\left({ }^{187} \mathrm{Os} /{ }^{188} \mathrm{Os}_{\mathrm{i}}=0.1273-0.1329\right)$ and subchondritic to chondritic Re/Os ratios $(0.04-0.11)$. The gently sloping HSE patterns with increasing depletion towards Au show concentrations in the range of other lherzolites from MOR or continental setting. Sulphur contents are high and variable (202-1268 ppm), and were likely increased during serpentinisation. By contrast, Se/Te ratios and concentrations are within the range of primitive mantle (PM) values, meaning that these elements were not significantly mobilised during serpentinisation.

Although displaying homogenous petrographic and geochemical features, the harzburgites are characterised by extremely heterogeneous Re-Os and HSE compositions.

Type-A harzburgites exhibit subchondritic ${ }^{187} \mathrm{Os} /{ }^{188} \mathrm{Os}_{\mathrm{i}}(0.1203-0.1266)$ and low Re/Os ratios $(0.01-0.04)$. The strong IPGE-PPGE fractionations $\left(\mathrm{Pd}_{\mathrm{N}} / \mathrm{Ir}_{\mathrm{N}}=0.21-0.56\right)$, coupled with positive Pt anomalies and S-Se-Te abundances often below the detection limit, suggest high melt extraction rates, resulting in sulphide consumption and Os-Ru metal alloy stabilisation.

Type-B harzburgites possess strongly fractionated, Os-Ir-Pt poor ( Os $=0.003-0.072 \mathrm{ng} / \mathrm{g}$, Ir $=0.0015-0.079 \mathrm{ng} / \mathrm{g}$ ) and $\mathrm{Pd}-$ Re enriched patterns, associated with chondritic to suprachondritic measured ${ }^{187} \mathrm{Os} /{ }^{188} \mathrm{Os}(0.127-0.153)$. These characters are uncommon for highly depleted mantle residues. Interaction with an oxidised component does not appear as a viable mechanism to account for the IPGE-depleted patterns of type-B harzburgites, as calculated oxygen fugacities are close to the FMQ buffer ( $\log \triangle \mathrm{FMQ}=0.35$ to 0.65$)$.

The strikingly uniform mineralogical and geochemical features displayed by both harzburgite sub-types suggest that the different HSE patterns are not linked to their recent evolution, implying that subduction-related processes were superimposed on geochemical heterogeneous mantle domains, which exerted an important control on HSE behaviour during melt extraction and post melting metasomatism.

We propose that the HSE characters of the studied peridotites reflect the presence of a highly heterogeneous mantle source with a long term (>1 Ga) evolution, possibly linked to the Zealandia formation. 


\section{Introduction}

Highly siderophile elements (HSE: PGE $+\mathrm{Au}-\mathrm{Re}$ ) are powerful geochemical tracers that can provide useful information for a variety of mantle processes, such as mantle melting, metasomatism and meltfluid/mantle interaction (e.g. Ackerman et al., 2009; Lorand et al., 2008; Luguet et al., 2001, 2003, 2007). However, our knowledge concerning the behaviour of HSE in mantle source rocks of primitive arc magmas and the role of the subduction zone environment on HSE partitioning (i.e. hydrous melting, melt/fluid-mantle interaction) still remains quite fragmentary. Furthermore, although abundant HSE data are now available for different types of mantle peridotites, HSE data on fore-arc peridotites are remarkably scarce (e.g. Becker and Dale, 2016).

The New Caledonia ophiolite (Peridotite Nappe) hosts one of the largest and best preserved mantle sections worldwide, providing an excellent opportunity to investigate upper mantle processes. The rock exposures are dominated by harzburgite tectonites bearing a suprasubduction zone affinity (Marchesi et al., 2009; Pirard et al., 2013; Secchiari et al., 2020; Ulrich et al., 2010). The main geochemical and isotopic features of these rock-types reflect a complex polyphase evolution, including several melting episodes in different geodynamic settings and subduction zone metasomatism (Marchesi et al., 2009; Secchiari et al., 2020; Ulrich et al., 2010). Minor spinel and plagioclase lherzolites, with compositions similar to abyssal peridotites, occur as discrete bodies in the north-western part of the island. The lherzolites record a different history compared to the extremely refractory harzburgites, as highlighted by their different geochemical signature (Secchiari et al., 2016; Ulrich et al., 2010).
In this work, a set of fully characterised peridotites (i.e. whole rock and in situ major and trace element contents, $\mathrm{Sr}-\mathrm{Nd}-\mathrm{Pb}$ isotopes) from New Caledonia (Secchiari et al., 2016, 2019, 2020) has been used to investigate Re-Os, HSE and chalcophile element (S-Se-Te) systematics. The main aims of this work are: 1) to examine the behaviour of these elements in the lherzolites (i.e. presumed abyssal peridotites) and in the ultra-depleted harzburgites, which may represent rocks from a former supra-subduction zone mantle wedge; 2 ) to constrain the behaviour of HSE and chalcophile elements during subduction zone processes.

\section{Geological setting and petrological background}

New Caledonia is a NW-SE elongated island located in the SW Pacific region, between the eastern margin of Australia and the Vanuatu archipelago (Figs. 1 and 2a). The island represents the emerged portion of the submarine Norfolk Ridge and it is composed by a mosaic of volcanic, sedimentary and metamorphic terranes, ranging in age from Permian to Miocene (Aitchison et al., 1995; Cluzel et al., 2001, 2012; Lagabrielle et al., 2013). These terranes were amalgamated during two major tectonic events: 1) an Early Cretaceous tectonic convergence phase (Paris, 1981) and 2) a Paleocene to Late Eocene subduction culminated in the obduction of the ophiolite. Both events were characterised by high-pressure low-temperature (HP-LT) metamorphism in connection with plate convergence. New Caledonia can be sub-divided into four main geological domains (Cluzel et al., 2001; see Fig. 1): (i) the Basement units (pre-Late Cretaceous basement and Late Coniacian-to-Late Eocene sedimentary cover), (ii) the

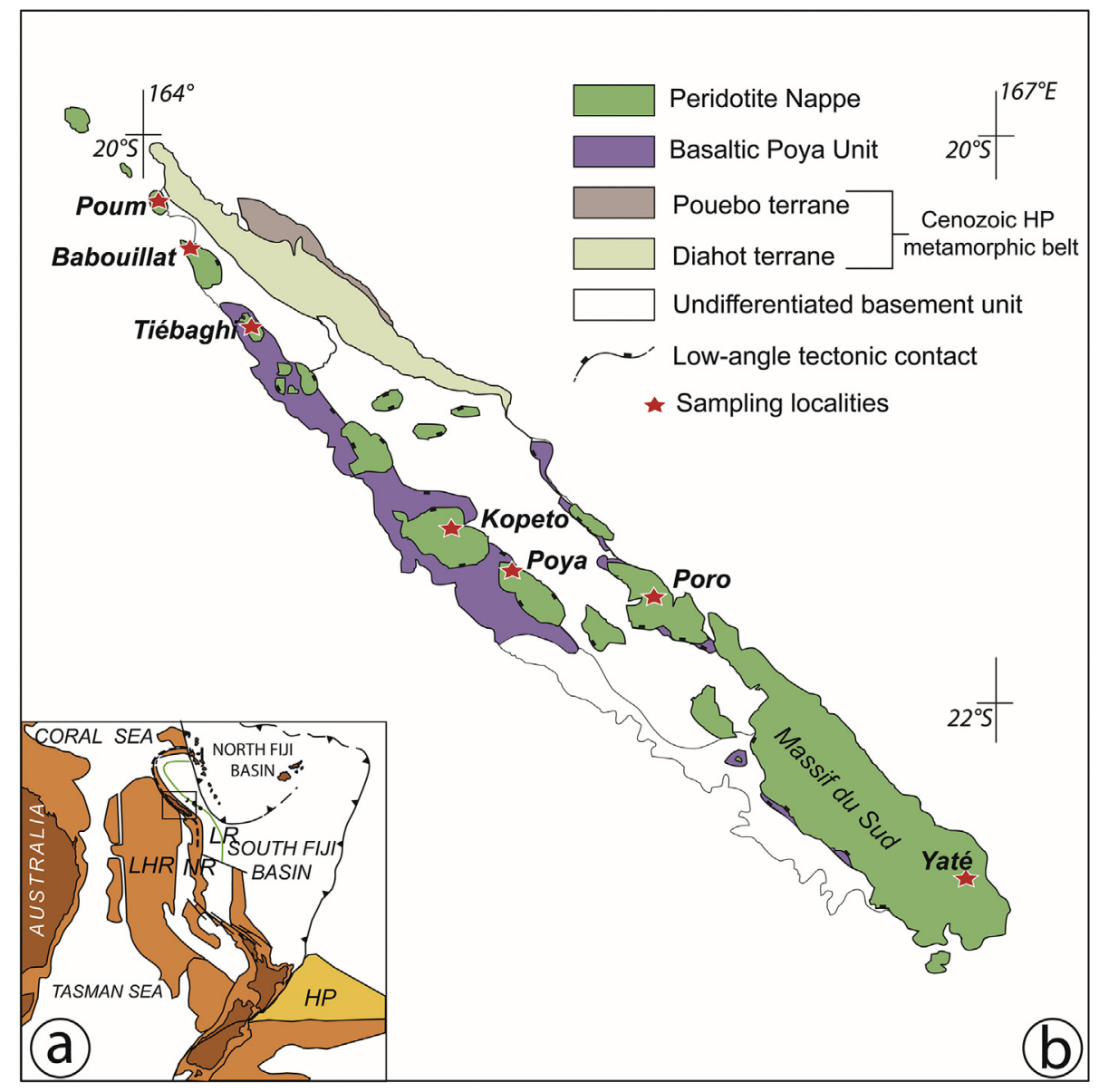

Fig. 1. a) Present-day structures of the Southwest Pacific region modified after Cluzel et al. (2012). Dark orange, land; light orange, continental plateau; white, oceanic basins (LHR: Lord Howe Rise, NR: Norfolk ridge, LR: Loyalty ridge, HP: Hikurangi Plateau); b) simplified geological map of New Caledonia showing distribution of the Peridotite massifs (modified after Cluzel et al., 2012). (For interpretation of the references to colour in this figure legend, the reader is referred to the web version of this article.) 

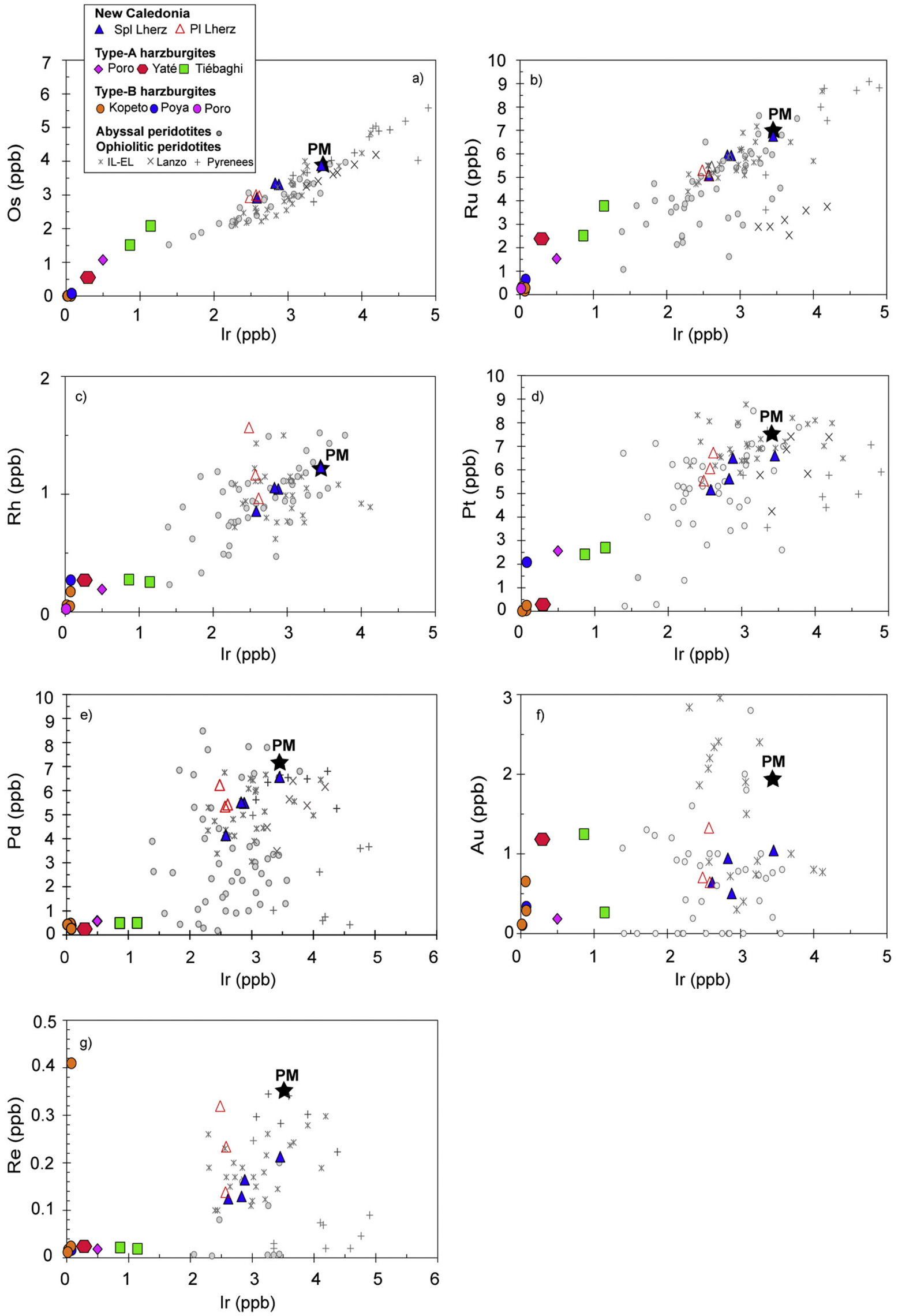

Fig. 2. Variations of Os, Ru, Rh, Pt, Pd, Au and Re vs. Ir for the New Caledonia peridotites. Abyssal peridotites (Kane fracture zone: Snow and Schmidt, 1998; Brandon et al., 2000; Luguet et al., 2001, 2003; Marchesi et al., 2013; MAR: Harvey et al., 2006; Lena trough: Lassiter et al., 2014) and ophiolitic peridotites (IL-EL: Internal and External Ligurides, Snow et al., 2000; Luguet et al., 2004; Fischer-Gödde et al., 2011; Lanzo: Becker et al., 2006; Pyrenees: Becker et al., 2006; Luguet et al., 2007) are shown for comparison 
Table 1

Concentrations of the HSE, S, Se and Te, Os isotopes, selected major elements and ratios for the New Caledonia peridotites.

\begin{tabular}{|c|c|c|c|c|c|c|c|c|c|c|c|c|c|c|c|}
\hline Sample & Rock & $\begin{array}{l}\mathrm{Al}_{2} \mathrm{O}_{3} \\
w t \%\end{array}$ & $\begin{array}{l}\text { LOI } \\
\%\end{array}$ & $\begin{array}{l}\text { Os } \\
(n g / g)\end{array}$ & $\begin{array}{l}\text { Ir } \\
(n g / g)\end{array}$ & $\begin{array}{l}\mathrm{Ru} \\
(\mathrm{ng} / \mathrm{g})\end{array}$ & $\begin{array}{l}\text { Rh } \\
(n g / g)\end{array}$ & $\begin{array}{l}\mathrm{Pt} \\
(\mathrm{ng} / \mathrm{g})\end{array}$ & $\begin{array}{l}\mathrm{Pd} \\
(n g / g)\end{array}$ & $\begin{array}{l}\mathrm{Au} \\
(n g / g)\end{array}$ & $\begin{array}{l}\operatorname{Re} \\
(n g / g)\end{array}$ & $0 s_{N} / I_{N}$ & $\mathrm{Os}_{\mathrm{N}} / \mathrm{Ru}_{\mathrm{N}}$ & $\mathrm{Pd}_{\mathrm{N}} / \mathrm{Ir}_{\mathrm{N}}$ & $\mathrm{Ru}_{\mathrm{N}} / \mathrm{Ir}_{\mathrm{N}}$ \\
\hline POU1A & Pl L & 2.49 & 7.56 & 2.93 & 2.48 & 5.31 & 1.57 & 5.54 & 6.23 & 0.704 & 0.319 & 1.06 & 0.99 & 1.24 & 1.07 \\
\hline POU2 & Sp L & 1.46 & 8.63 & 3.88 & 3.45 & 6.76 & 1.23 & 6.60 & 6.56 & 1.04 & 0.213 & 1.01 & 0.18 & 0.94 & 5.71 \\
\hline POU2B & Sp L & 2.57 & 10.69 & 3.31 & 2.88 & 5.93 & 1.04 & 6.49 & 5.49 & 0.503 & 0.165 & 1.03 & 1.09 & 0.94 & 0.95 \\
\hline POU3 & Sp L & 1.30 & 9.60 & 2.91 & 2.58 & 5.07 & 0.86 & 5.15 & 4.14 & 0.642 & 0.234 & 1.01 & 1.05 & 0.79 & 0.97 \\
\hline BA1 & Sp L & 1.74 & 6.39 & 3.34 & 2.85 & 5.95 & 1.05 & 5.62 & 5.51 & 0.943 & 0.129 & 1.06 & 0.27 & 0.96 & 3.88 \\
\hline BAB1B & Pl L & 2.61 & 6.98 & 2.96 & 2.61 & 5.46 & 0.965 & 6.73 & 5.42 & 0.641 & 0.125 & 1.02 & 0.24 & 1.02 & 4.30 \\
\hline BAB2B & $\mathrm{Pl} \mathrm{L}$ & 2.83 & 8.43 & 3.00 & 2.57 & 5.08 & 1.16 & 6.06 & 5.33 & 1.33 & 0.138 & 1.05 & 1.67 & 1.02 & 0.63 \\
\hline TI1 & $\mathrm{H}$ & 0.78 & 9.01 & 1.51 & 0.864 & 2.52 & 0.275 & 2.42 & 0.488 & 1.25 & 0.022 & 1.57 & 1.08 & 0.28 & 1.46 \\
\hline TI2 & $\mathrm{H}$ & 1.03 & 6.04 & 2.07 & 1.14 & 3.78 & 0.254 & 2.70 & 0.499 & 0.264 & 0.019 & 1.63 & 0.98 & 0.21 & 1.65 \\
\hline PO4 & $\mathrm{H}$ & 0.43 & 0.18 & 1.07 & 0.499 & 1.53 & 0.191 & 2.56 & 0.570 & 0.160 & 0.018 & 1.93 & 1.26 & 0.56 & 1.53 \\
\hline YA1 & $\mathrm{H}$ & 0.46 & 6.83 & 0.554 & 0.297 & 2.35 & 0.326 & 0.268 & 0.263 & 1.17 & 0.022 & 1.67 & 0.42 & 0.44 & 3.95 \\
\hline PY1 & $\mathrm{H}$ & 0.78 & 0.00 & 0.049 & 0.077 & 0.643 & 0.269 & 2.08 & 0.378 & 0.336 & 0.016 & 0.58 & 0.14 & 2.43 & 4.19 \\
\hline Duplicate & & & & 0.023 & 0.133 & 0.693 & 0.171 & 2.44 & 0.588 & 0.311 & 0.062 & & & & \\
\hline КРT2 & $\mathrm{H}$ & 0.70 & 3.03 & 0.004 & 0.022 & 0.323 & 0.057 & 0.078 & 0.431 & 0.107 & 0.018 & 0.18 & 0.02 & 9.50 & 7.22 \\
\hline Duplicate & & & & 0.036 & 0.017 & 0.211 & 0.040 & 0.210 & 0.620 & 0.144 & 0.010 & & & & \\
\hline КРТ5 & $\mathrm{H}$ & 0.74 & 0.12 & 0.004 & 0.066 & 0.165 & 0.048 & 0.038 & 0.464 & 0.654 & 0.024 & 0.05 & 0.04 & 3.46 & 1.25 \\
\hline Duplicate & & & & 0.007 & 0.062 & 0.165 & 0.054 & 0.046 & 0.512 & 0.603 & 0.056 & & & & \\
\hline PO3 & $\mathrm{H}$ & 0.41 & 0.00 & 0.003 & 0.015 & 0.256 & 0.023 & 0.006 & 0.428 & 0.084 & 0.012 & 0.18 & 0.02 & 14.12 & 8.57 \\
\hline Duplicate & & & & 0.055 & 0.018 & 0.243 & 0.016 & 0.009 & 0.573 & 0.293 & 0.008 & & & & \\
\hline КРТ3 & $\mathrm{H}$ & 0.67 & 0.67 & 0.072 & 0.079 & 0.280 & 0.172 & 0.248 & 0.250 & 0.288 & 0.410 & 0.81 & 1.87 & 0.17 & 0.19 \\
\hline
\end{tabular}

Cenozoic HP-LT metamorphic belt, (iii) the basaltic Poya Terrane and (iv) a large slab of peridotites, named the Peridotite Nappe.

The Peridotite Nappe represents an allochtonous sheet of oceanic lithosphere belonging to the former South Loyalty basin thrust on the continental basement of the Norfolk Ridge at the end of the Eocene subduction. The emplacement of the ophiolitic nappe resulted from the failed subduction of the Norfolk Ridge tip in a NE-dipping subduction zone, which culminated in the obduction of the Loyalty subarc lithosphere 34 Ma ago (Cluzel et al., 2012).

The Peridotite Nappe has an extension of about $8000 \mathrm{~km}^{2}$ and is mostly exposed in the Massif du Sud, where a thick harzburgitedunite unit, locally overlain by kilometre-scale lenses of mafic and ultramafic intrusives, crops out. The sequence is believed to represent a crust-mantle boundary that records the onset of the Eocene subduction in a nascent arc setting (Marchesi et al., 2009; Pirard et al., 2013; Secchiari et al., 2018). Recent geochemical studies have shown that the ultramafic intrusives (i.e. dunites and wehrlites) crystallised from variably depleted melts with island arc basalt affinity, after massive interactions with the underlying harzburgite (Marchesi et al. 2009; Pirard et al., 2013). In contrast, the mafic rocks (i.e. gabbronorites) have a cumulate origin (Marchesi et al., 2009; Pirard et al., 2013; Secchiari et al., 2018) and derive from crystallisation of primitive, non-aggregated, ultra-depleted melts showing involvement of a subduction-related component in their source (Secchiari et al., 2018).

The harzburgites are also exposed in the northern Tiébaghi massif (Ulrich et al., 2010) or as sparse tectonic klippen in the central part of the island (e.g. Kopeto, Poya, Koniambo), where exceptionally fresh peridotites display primary mineral assemblages similar to the more serpentinised rocks of the Massif du Sud.

The New Caledonia harzburgites bear an overall ultra-depleted composition, inherited from a complex multistage evolution linked to the development of the Eocene subduction system (Marchesi et al., 2009; Secchiari et al., 2020; Ulrich et al., 2010). Geochemical studies have proposed that the harzburgites formed by high degrees of fluid-assisted melting (up to $20-25 \%$ in a supra-subduction zone environment, see Marchesi et al., 2009; Ulrich et al., 2010). More recently, the work of Secchiari et al. (2020) provided further constraints on the evolution of these rock-types, tracking their history from melting to late stage metasomatism. Accordingly, the harzburgites underwent two partial melting episodes in the spinel stability field: a first melting phase in a MOR setting ( $15 \%$ melting degrees), followed by hydrous melting in a supra-subduction zone setting (up to $18 \%$ fluid-assisted melting). Post-melting cooling and re-equilibration at lithospheric conditions was accompanied by interaction with ultra-depleted slab-derived hydrous melts (Secchiari et al., 2019, 2020). These metasomatic processes are testified in the harzburgites by the widespread occurrence of secondary metasomatic phases (i.e. thin films of $\mathrm{Al}_{2} \mathrm{O}_{3}-$, $\mathrm{CaO}-$ poor orthopyroxene, and low $\mathrm{Al}_{2} \mathrm{O}_{3}$ and $\mathrm{Na}_{2} \mathrm{O}$ clinopyroxene), L-MREE and $\mathrm{Zr}$ - Hf bulk rock enrichments, and possibly by the poorly radiogenic Nd isotopic ratios shown by some samples (Secchiari et al., 2020).

Compared to the harzburgites from the central and the southern massifs, Tiébaghi samples display a more fertile nature, as revealed by the higher bulk trace element concentrations as well as by the occurrence of a small fraction (up to $4 \mathrm{vol} \%$ ) of clinopyroxene (see Ulrich et al., 2010; Secchiari, $2016 \mathrm{PhD}$ thesis).

The main geochemical and petrological features of the spinel and plagioclase lherzolites are thought to reflect moderate melt extraction degrees (8-9\%) in a MOR environment, followed by refertilisation by depleted MORB-type melts, yielding plagioclase lherzolites. The main petrological and geochemical features of the lherzolites have been reported in detail by Secchiari et al. (2016).

\subsection{Sample description}

In this contribution, sixteen samples of peridotites fully characterised for lithophile element geochemistry (i.e. major, trace element and $\mathrm{Sr}-\mathrm{Nd}-\mathrm{Pb}$ isotope compositions) were analysed for mass fractions of all PGE, Re, Au, S, Se, Te and ${ }^{187} \mathrm{Os} /{ }^{188} \mathrm{Os}$. Detailed descriptions of the lherzolites and harzburgites, including trace element chemistry and $\mathrm{Sr}-\mathrm{Nd}-\mathrm{Pb}$ isotopes, are provided in the works of Secchiari et al. (2016) and Secchiari et al. (2019, 2020), respectively.

Lherzolite samples are from the Poum and Babouillat areas, while the harzburgites were collected from several outcrops and mine zones along the island: Yaté, Kopeto, Poya, Poro and Tiébaghi (Fig. 1b and Table 1). The lherzolites include slightly serpentinised (LOI = 6.9-10.7\%) spinel and plagioclase lherzolites, while the harzburgites are typically not or only weakly serpentinised ( $\mathrm{LOI}=0-3 \%$ ), except for samples YA1, TI1 and TI2 ( $\mathrm{LOI}=6.0-9.0 \%$ ).

Both lherzolites and harzburgites are low strain mantle tectonites, showing dominant porphyroclastic textures (Fig. S1a-b) and local protomylonite development. Spinel lherzolites have 7-8 vol\% 


\begin{tabular}{|c|c|c|c|c|c|c|c|c|c|c|c|c|c|c|}
\hline $\mathrm{Pt}_{\mathrm{N}} / \mathrm{Ir}_{\mathrm{N}}$ & $\mathrm{Pt}_{\mathrm{N}} / \mathrm{Ru}_{\mathrm{N}}$ & $\begin{array}{l}{ }^{187} \mathrm{Re} /{ }^{188} \mathrm{Os} \\
(2 \mathrm{SE})\end{array}$ & $\begin{array}{l}{ }^{187} \mathrm{Os} /{ }^{188} \mathrm{Os} \\
\text { measured }\end{array}$ & 2SE & ${ }^{187} \mathrm{Os} /{ }^{188} \mathrm{Os}_{\mathrm{i}}$ & $\begin{array}{l}\gamma \mathrm{Os} \\
\text { (53Ma) }\end{array}$ & $\begin{array}{l}\mathrm{T}_{\mathrm{MA}} \\
\text { (PM) } \\
\mathrm{Ga}\end{array}$ & $\begin{array}{l}\mathrm{T}_{\mathrm{RD}} \\
(\mathrm{PM}) \\
\mathrm{Ga}\end{array}$ & $\begin{array}{l}\mathrm{T}_{\mathrm{RD} 2} \\
(\mathrm{PM}) \\
\mathrm{Ga}\end{array}$ & $\begin{array}{l}\mathrm{S} \\
(\mu \mathrm{g} / \mathrm{g})\end{array}$ & $\begin{array}{l}\text { Se } \\
(n g / g)\end{array}$ & $\begin{array}{l}\mathrm{Te} \\
(n g / g)\end{array}$ & $\mathrm{S} / \mathrm{Se}$ & $\mathrm{Se} / \mathrm{Te}$ \\
\hline 1.03 & 0.96 & $0.525(1)$ & 0.130822 & $9.1 \mathrm{E}-06$ & 0.130358 & 2.9 & 0.8 & $\mathrm{f}$ & f & 202 & 74.9 & 11.5 & 2703 & 6.5 \\
\hline 0.88 & 0.15 & $0.265(1)$ & 0.127574 & $6.8 \mathrm{E}-06$ & 0.127340 & 0.5 & 0.7 & $\mathrm{f}$ & 0.3 & 582 & 69.6 & 11.6 & 8364 & 6.0 \\
\hline 1.04 & 1.09 & $0.240(1)$ & 0.128227 & $8.0 \mathrm{E}-06$ & 0.128016 & 1.1 & 0.4 & $\mathrm{f}$ & 0.2 & 1268 & 77.8 & 10.8 & 16,289 & 7.2 \\
\hline 0.92 & 0.95 & $0.387(1)$ & 0.131356 & $9.1 \mathrm{E}-06$ & 0.131015 & 3.4 & f & $\mathrm{f}$ & f & 362 & 54.0 & 7.3 & 6691 & 7.4 \\
\hline 0.92 & 0.24 & $0.186(1)$ & 0.131485 & $7.9 \mathrm{E}-06$ & 0.131320 & 3.7 & f & $\mathrm{f}$ & $\mathrm{f}$ & 294 & 91.3 & 13.8 & 3218 & 6.6 \\
\hline 1.19 & 0.28 & $0.202(1)$ & 0.129664 & $8.9 \mathrm{E}-06$ & 0.129485 & 2.2 & f & $\mathrm{f}$ & 0.0 & 327 & 66.2 & 9.5 & 4943 & 7.0 \\
\hline 1.09 & 1.73 & $0.223(1)$ & 0.133084 & $8.9 \mathrm{E}-06$ & 0.132887 & 4.9 & $f$ & f & f & 289 & 67.6 & 9.8 & 4278 & 6.9 \\
\hline 1.29 & 0.89 & $0.070(25)$ & 0.12479 & $1.7 \mathrm{E}-05$ & 0.12473 & -1.5 & 0.8 & 0.7 & 0.7 & 9 & 1.1 & 1.0 & 8188 & 1.0 \\
\hline 1.09 & 0.66 & $0.045(18)$ & 0.12662 & $1.3 \mathrm{E}-05$ & 0.12658 & -0.1 & 0.5 & 0.4 & 0.4 & 10 & 0.7 & 0.4 & 14,053 & 1.7 \\
\hline 2.36 & 1.54 & $0.081(35)$ & 0.12040 & $2.4 \mathrm{E}-05$ & 0.12033 & -5.0 & 1.5 & 1.3 & 1.3 & 6 & 3.1 & 0.8 & 2084 & 4.1 \\
\hline 0.42 & 0.11 & $0.196(68)$ & 0.12551 & $4.7 \mathrm{E}-05$ & 0.12534 & -1.0 & 1.0 & 0.6 & 0.6 & 40 & 4.9 & 0.4 & 8117 & 11.4 \\
\hline \multirow[t]{2}{*}{2.97} & 2.97 & $1.62(8)$ & 0.1299 & $5.3 \mathrm{E}-04$ & 0.1284 & 1.4 & 0.0 & 0.0 & 0.2 & 6 & 0.9 & 0.9 & 6103 & 1.1 \\
\hline & & $13.0(1)$ & 0.127 & $1.0 \mathrm{E}-03$ & 0.115 & -8.9 & & & & 53 & 0.3 & 1.0 & 196,197 & 0.3 \\
\hline \multirow[t]{2}{*}{0.22} & 0.22 & $19(1)$ & 0.148 & $5.6 \mathrm{E}-03$ & 0.131 & 3.6 & 0.1 & $\mathrm{f}$ & $\mathrm{f}$ & 5 & 1.3 & 0.4 & 4164 & 2.8 \\
\hline & & $1.4(1)$ & 0.302 & $1.3 \mathrm{E}-03$ & 0.301 & 137.8 & & & & 7 & 1.3 & 8.2 & 4947 & 0.2 \\
\hline \multirow[t]{2}{*}{0.21} & 0.21 & $32(2)$ & 0.147 & $6.2 \mathrm{E}-03$ & 0.118 & -6.6 & 0.0 & f & $\mathrm{f}$ & 3 & 3.0 & 0.7 & 1133 & 4.1 \\
\hline & & $37(1)$ & 0.160 & $3.2 \mathrm{E}-03$ & 0.127 & 0.5 & & & & 3 & 0.7 & 1.3 & 4453 & 0.5 \\
\hline \multirow[t]{2}{*}{0.02} & 0.02 & $19(2)$ & 0.153 & $8.4 \mathrm{E}-03$ & 0.136 & 8.0 & 0.1 & $\mathrm{f}$ & $\mathrm{f}$ & 3 & 1.4 & 0.6 & 2129 & 2.2 \\
\hline & & $0.69(7)$ & 0.1239 & 4.7E- 04 & 0.1233 & & & & & bdl & bdl & 0.8 & - & - \\
\hline 6.92 & 6.92 & $28(1)$ & 0.1273 & $3.5 \mathrm{E}-04$ & 0.1204 & -5.1 & 0.0 & 0.3 & 1.3 & 6 & bdl & bdl & - & - \\
\hline
\end{tabular}

Duplicate: replicate digestion of the same sample powder.

$\mathrm{Pl} \mathrm{L}=$ plagioclase lherzolite, $\mathrm{Sp} \mathrm{L}=$ spinel lherzolite, $\mathrm{H}=$ harzburgite

Values of $\mathrm{PM}{ }^{187} \mathrm{Os} /{ }^{188} \mathrm{Os}=0.1296$ and ${ }^{187} \mathrm{Re} /{ }^{188} \mathrm{Os}=0.434$ used for calculation of $\mathrm{T}_{\mathrm{MA}}$ and $\mathrm{T}_{\mathrm{RD}}$ ages (Meisel et al., 2001); $\mathrm{f}=$ future model ages. $\mathrm{T}_{\mathrm{RD} 2}$ (PM) indicates depletion ages calculated taking into account Re addition that may have occurred during peridotite evolution.

clinopyroxene and display a typical abyssal-type REE signature. The plagioclase lherzolites show melt impregnation microstructures (Fig. S1b) and are slightly enriched in incompatible trace element (REE, Ti, Y, and $\mathrm{Zr}$ ) with respect to the spinel lherzolites. Harzburgites are extremely depleted rocks, as highlighted by the general absence of clinopyroxene (with the exception of sample TI2, where clinopyroxene is 4 vol\%, Fig. S1c) and remarkably low incompatible trace element contents (Secchiari et al., 2020). The primary mantle assemblage is composed of olivine, orthopyroxene and spinel. The occurrence of thin films of metasomatic ortho- and clinopyroxene (Fig. S1d) was interpreted as resulting from percolation of small fractions of subduction-related magmas (Secchiari et al., 2019, 2020).

All the lherzolites studied here contain trace amounts of sulphides with variable size, shape and position. Sulphides in five selected samples (i.e. BA1, POU2, POU3, POU1A, BAB1B, see Table S1) were analysed for their major element chemistry composition.

Frequent interstitial sulphide grains occur as polyhedral blebs, rounded or irregular-shaped grains (Fig. S2a-d-e), generally located at olivine-orthopyroxene or at olivine-olivine grain boundaries. They range from tiny crystals $(\sim 60 \times 30 \mu \mathrm{m})$ up to $300 \times 100 / 150 \mu \mathrm{m}$ in maximum dimensions. Enclosed sulphides hosted within large olivine porphyroclasts have been also observed. Sulphide inclusions (Fig. S2ae) have variable size ( 30 to $80 \mu \mathrm{m} \times 60$ to $150 \mu \mathrm{m}$ ) and shape, from polyhedral to spherical.Very tiny enclosed sulphide grains $(\sim 5-6 \mu \mathrm{m} \times 10 \mu \mathrm{m})$ have been recognised in sample POU1A.

Major element composition of the sulphide phases is relatively homogeneous (Table S1 and Fig. S2, S3), showing no significant difference among enclosed and interstitial sulphides. Chemical composition of the studied sulphides mainly fall in the field of $\mathrm{Ni}$-poor $(\mathrm{Fe} / \mathrm{Ni}=1.3-2.1)$ monosulphide solid solution + Liquid (Fig. S3), but Ni-rich $(\mathrm{Fe} / \mathrm{Ni}=$ 0.7-0.8) pentlandite, resulting from cooling and re-equilibration (Guo et al., 1999), has been also identified in four of the investigated samples (POU2, POU3, POU1A, BAB1B).

In the harzburgites, sulphide phases have not been identified, nor through petrographic observation or microprobe analyses. This is consistent with the refractory nature and the high melt extraction rates experienced by these rock-types, which prevented sulphide retention in the residual mantle source.

\section{Analytical methods}

\subsection{HSE and chalcophile elements}

Seven lherzolites and nine harzburgites (including four duplicates) have been analysed in the geochemistry laboratory at Freie Universität for HSE, S, Se, Te mass fractions in whole rocks and ${ }^{187} \mathrm{Os} /{ }^{188} \mathrm{Os}$.

Detailed procedure descriptions have been given in previous works from this laboratory (e.g. Fischer-Gödde et al., 2011; Wang et al., 2013; Wang and Becker, 2013). The methods will only be briefly summarised below.

About $2.5 \mathrm{~g}$ of sample powder was weighed into $90 \mathrm{~mL}$ quartz glass digestion vessels and spiked with mixed ${ }^{191} \mathrm{Ir}-{ }^{99} \mathrm{Ru}-{ }^{194} \mathrm{Pt}-{ }^{105} \mathrm{Pd}$, ${ }^{77} \mathrm{Se}-{ }^{125} \mathrm{Te},{ }^{185} \mathrm{Re}-{ }^{190} \mathrm{Os}$ and ${ }^{34} \mathrm{~S}$ solutions. Then, $5 \mathrm{~mL} 14 \mathrm{~mol} / \mathrm{L}, \mathrm{N}_{2}-$ bubbled $\mathrm{HNO}_{3}$ and $2.5 \mathrm{~mL} 9 \mathrm{~mol} / \mathrm{L} \mathrm{HCl}$ were added. The vessels were immediately sealed with Teflon tape and samples were digested for $16 \mathrm{~h}$ at $320^{\circ} \mathrm{C}$ and 100 bar. After digestion, osmium was extracted from the reverse aqua regia into chloroform, back extracted into $\mathrm{HBr}$ (Cohen and Waters, 1996), and further purified by micro distillation from a $\mathrm{H}_{2} \mathrm{SO}_{4}$-dichromate solution into $15 \mu \mathrm{L}$ of $\mathrm{HBr}$ (Birck et al., 1997)

Osmium isotopes were determined as $\mathrm{OsO}_{3}^{-}$in negative mode using the Thermo Finnigan Triton TIMS, using a secondary electron multiplier. Signal intensities of the spike isotope ${ }^{190} \mathrm{Os}$ of samples were $\sim 150,000-500,000$ cps. Standard runs with different amounts of Os on the filament ( $10 \mathrm{pg}$ and $100 \mathrm{pg}$ ) were also run in between the studied samples, yielding an average value of $0.1139 \pm 0.0002$ ( 2 s. d., $n=$ 24 ) for 100 pg loads. Two hundreds scans were collected in each measurement for high-Os samples, while at least 120-140 scans were obtained for the low-Os samples. Raw data were corrected for isobaric $\mathrm{OsO}_{3}^{-}$interferences, mass fractionation using the ${ }^{192} \mathrm{Os} /{ }^{188} \mathrm{Os}$ ratio of 3.08271, contributions from the Os spike solution and blank contributions. ${ }^{187} \mathrm{Os} /{ }^{188} \mathrm{Os}$ were finally adjusted relative to the mean of the Os standard. The oxygen isotope compositions used for the oxide correction of Os oxide molecules were ${ }^{18} \mathrm{O} /{ }^{16} \mathrm{O}$ of 0.00204 and ${ }^{17} \mathrm{O} /{ }^{16} \mathrm{O}$ of 0.00037 (Nier, 1950).

About $50 \%$ of the digestion solution was used for separation of the HSE fraction and about $30 \%$ for S-Se-Te separation. Chemical separation of the HSE fraction from the matrix was performed on columns filled 
with $10 \mathrm{~mL}$ of pre-cleaned Eichrom $50 \mathrm{~W}$-X8 (100-200 mesh) cation exchange resin (Fischer-Gödde et al., 2011). During separation, the HSE fraction was collected in $14 \mathrm{~mL} 0.5 \mathrm{~mol} / \mathrm{L} \mathrm{HCl}-40 \mathrm{vol} \%$ acetone mixture. After the volume of the solution has been reduced to about $2 \mathrm{~mL}$ it was analysed for $\mathrm{Au}, \mathrm{Re}$, Ir and Pt. In order to remove interfering $\mathrm{Cd}$, the remaining solution was further purified in $0.2 \mathrm{~mol} / \mathrm{L} \mathrm{HCl}$ on $3 \mathrm{~mL}$ Eichrom $50 \mathrm{~W}-\mathrm{X} 8$ (100-200 mesh) resin. The collected solution was evaporated to near dryness and the residue was taken up in $0.28 \mathrm{M}$ $\mathrm{HNO}_{3}$ for ICP-MS analysis. The analyses were carried out using a single collector Element XR instrument. We used either a Scott-type spray chamber (Re, Ir, Pt, Au) or an Aridus-I desolvator (Ir, Ru, Pt, Rh, Pd) at an oxide formation rate of $\mathrm{CeO}^{+} / \mathrm{Ce}^{+}<0.004$.

A two-step ion exchange chromatography method was used for separation of S, Se and Te (see Wang et al., 2013). Sulphur measurements were performed on the $\mathrm{S}-\mathrm{Se}$ fraction at medium mass resolution mode on the Element XR. Selenium and Tellurium were measured using a double pass Scott type glass spray chamber at low mass resolution mode on the Element XR, combined with a hydride generation sample introduction system by reacting the sample solution with $1 \mathrm{~g} /$ $100 \mathrm{~g} \mathrm{NaBH}_{4}$ in $0.05 \mathrm{~mol} / \mathrm{L} \mathrm{NaOH}$ (see Wang et al., 2013 for details).

For each batch of analysis, one procedural blank has been used. Procedural blanks yielded the following mean values ( \pm 1 s.d., $n=4-5$ ): $\mathrm{Re}=2.5 \pm 2.0 \mathrm{pg} ; \mathrm{Os}=0.5 \pm 0.3 \mathrm{pg}$ with ${ }^{187} \mathrm{Os} /{ }^{188} \mathrm{Os}$ ratios of $0.14 \pm 0.03 ; \mathrm{Ir}=15 \pm 5 \mathrm{pg} ; \mathrm{Ru}=45 \pm 14 \mathrm{pg} ; \mathrm{Rh}=24 \pm 22 \mathrm{pg}$ $\mathrm{Pt}=23 \pm 29 \mathrm{pg} ; \mathrm{Pd}=640 \pm 330 \mathrm{pg} ; \mathrm{Au}=4 \pm 2 \mathrm{pg} ; \mathrm{Te}=1.1 \pm$ $0.8 \mathrm{ng} ; \mathrm{Se}=2.3 \pm 0.8 \mathrm{ng} ; \mathrm{S}=2.8 \pm 0.7 \mu \mathrm{g}$. Samples were corrected for total procedural blanks using the mean values. Blank corrections for Re are negligible for most of the analysed samples $(\leq 0.3-0.8 \%)$, but more significant for the harzburgites ( 4-8\%). Blank corrections for Pt and Pd are again negligible for the lherzolites $(\sim 0.2-0.3 \%)$, a few percents for the harzburgites $(\sim 0.4-4 \%$, with the exception of KPT2, KPT5 and PO3 for which the correction for Pt is 11-36\%). Blanks of Os, Ir $\mathrm{Ru}$ and $\mathrm{Rh}$ are insignificant for most of the samples $(\leq 0.4 \%)$ but higher for the most depleted harzburgites, i.e. KPT2, KPT5 ( 2-7\% for Os, Ir $\mathrm{Rh}$ ) and PO3 ( 9\% for Os and Ir, 13\% for Rh). Blank corrections for $\mathrm{S}$, Se and Te in lherzolites range between 1 and 1.7\% (S - Se) and 3-6\% (Te), while for the harzburgites blank corrections for these elements strongly affected the obtained results (corrections $\sim 10-26 \%$ for $S$ and up to $40-80 \%$ for Se and Te), given the very low measured abundances.

\subsection{Oxygen fugacity}

Iron oxidation state in studied spinels was measured using the "flank method" developed for the JEOL JXA-8200 electron microprobe at Freie Universität (Goncharov, 2018). The position shift and intensity variation of FeL $\alpha$ and FeL $\beta$ X-ray lines were investigated using as standards a collection of nineteen natural mantle spinels previously characterised by Mössbauer spectroscopy for their $\mathrm{Fe}^{3+} / \Sigma \mathrm{Fe}$ at IPGG RAS (St. Petersburg, see Goncharov and Ionov, 2012; Goncharov et al., 2015).

The analytical procedure was similar to the experiments performed over the last decades to study $\mathrm{Fe}^{3+} / \Sigma \mathrm{Fe}$ in mantle garnets after the "flank" approach developed by Höfer and Brey (2007).

The flank positions for the spectrometer were obtained from the difference spectrum of almandine and andradite with known iron oxidation state in the wavelength range related to FeL $\alpha$ and FeL $\beta$ lines. The intensities at flank positions near FeL $\alpha$ and FeL $\beta$ lines were collected as two fake elements, setting counting time at $300 \mathrm{~s}$ on both measurements, with 3 repetitions in the core and in the rim respectively, and considering 5 separate spinel grains within one thin section. Measurement conditions were $15 \mathrm{kV}$ and $60 \mathrm{nA}$ using TAP crystal for intensities at flank positions and with the remaining four spectrometers measuring chemical composition at the same spot simultaneously. The studied spinels show no significant core to rime zoning in terms of $\mathrm{FeO}$ content $\mathrm{Cr} \#$ and $\mathrm{FeL} \beta / \mathrm{FeL} \alpha$ ratio. Averaged FeL $\beta / \mathrm{FeL} \alpha$ ratios for each sample were used to calculate iron oxidation state of spinel using the equation with coefficients obtained after investigation of the standard collection (see Table 2).

\section{Results}

\subsection{HSE and chalcophile elements in spinel and plagioclase lherzolites}

HSE and chalcophile element compositions of the New Caledonia lherzolites are reported in Table 1 and displayed in Figs. 2, 3, 4. Spinel and plagioclase lherzolites are relatively homogeneous in terms of HSE, Se, Te concentrations, abundance patterns and Os isotopic compositions, with plagioclase-bearing samples showing indistinguishable patterns from those of spinel lherzolites. The concentrations of the highly siderophile and chalcophile elements are in the range of those observed for modern abyssal and ophiolitic peridotites, displaying good correlation for Ir group PGE (IPGE, e.g., Os vs. Ir and Ir vs. Ru) and more dispersed variations for the Pt group PGE (PPGE, Fig. S4). In primitive mantle (PM) normalised concentration diagrams (Fig. 3), the lherzolites exhibit flat or gently sloping negative patterns with similar PM-normalised PGE concentrations and depletions in $\mathrm{Au}$ (except for sample BAB2B) and Re compared to the PGE (with the exception of POU1A and POU3 for Re). Overall, absolute contents of the PGE are similar or slightly lower than primitive mantle (PM) values (Becker et al., 2006; Fischer-Gödde et al., 2011), overlapping the field of the abyssal peridotites and peridotite tectonites from continental settings (e.g., Fig. 2 and Becker and Dale, 2016). Ru/Ir and Pd/Ir ratios are suprachondritic, as observed for other mantle lherzolites (e.g. Becker et al., 2006; Lorand et al., 1999; Luguet et al., 2003; Rehkämper et al., 1999).

Initial ${ }^{187} \mathrm{Os} /{ }^{188} \mathrm{Os}$ ratios calculated at $53 \mathrm{Ma}$ (i.e. the inferred age of initial magmatism in the subduction system, e.g. Cluzel et al., 2006) vary from chondritic to slightly suprachondritic (0.1273-0.1329, Fig. 4a), corresponding to $\gamma \mathrm{Os}_{(53 \mathrm{Ma})}$ of 0.5 to 4.9 . These values overlap with data of abyssal peridotites and orogenic peridotites, but tend to be somewhat higher than for other mantle lherzolites bearing comparable depletion degrees (Fig. 4). ${ }^{187}$ Re $/{ }^{188}$ Os ranges from subchondritic to slightly suprachondritic values (0.186-0.525, see Fig. 4c).

Se and Te are positively correlated in the lherzolites (Fig. 5a) and range between 54 and $91.3 \mathrm{ng} / \mathrm{g}$ and 7.3-13.8 ng/g, $\mathrm{r}$ espectively. Se/ Te ratios (5.9-7.1) are slightly lower than the PM value and similar to the data previously obtained on depleted lherzolites (Wang and Becker, 2013). Se and Te do not display any correlation with PGE abundances, with the exception of Te, which shows a weak correlation with Pd (Fig. 5b). S contents are high and variable (202-1268 $\mu \mathrm{g} / \mathrm{g}$ ) compared to unserpentinised peridotites, leading to high $\mathrm{S} / \mathrm{Se}$ ratios (2703-16,289, Fig. 5c).

\subsection{HSE and chalcophile elements in harzburgites}

On the basis of HSE behaviour and Os isotopic compositions (Figs. 2, 3 and 6, Table 1), the studied harzburgites can be grouped into two different sub-types: type-A and type-B.

Type-A harzburgites (TI1, TI2, PO4 and YA1) are characterised by notably lower PGE and chalcophile elements mass fractions (Figs. 2,4) and more fractionated patterns (Fig. 6a) compared to the lherzolites. Mass fractions of the PGE are $1.07-2.07 \mathrm{ng} / \mathrm{g}$ for Os, $0.50-1.14 \mathrm{ng} / \mathrm{g}$ for Ir, 1.53-2.52 ng/g for Ru, $0.19-0.27 \mathrm{ng} / \mathrm{g}$ for Rh, $2.42-2.70 \mathrm{ng} / \mathrm{g}$ for Pt and $0.49-0.57 \mathrm{ng} / \mathrm{g}$ for Pd. Among the sub-group A, sample YA1 displays distinct PGE abundances, showing much lower Os, Ir, Pt, Pd contents ( $0.55 \mathrm{ppb}$ for Os, $0.30 \mathrm{ppb}$ for Ir, $0.27 \mathrm{ppb}$ for Pt and $0.26 \mathrm{ppb}$ for Pd), with exceptions for Ru, Rh, Au and S.

HSE and chalcophile element diagrams of type-A harzburgites display fractionated patterns, with concentrations decreasing from Os towards Re. Os and Ru are enriched compared to Ir, leading to correlated suprachondritic $\mathrm{Os} / \mathrm{Ir}$ and $\mathrm{Ru} / \mathrm{Ir}$ ratios $(\mathrm{Os} / \mathrm{Ir}=2.9-7.9 ; \mathrm{Ru} / \mathrm{Ir}=$ 1.8-2.1, Fig. 4). Pt and Au generally show positive spikes, more 
Table 2

Equilibration temperature, pressure, and oxygen fugacity calculated for selected peridotite samples. Average spinel compositions are also reported.

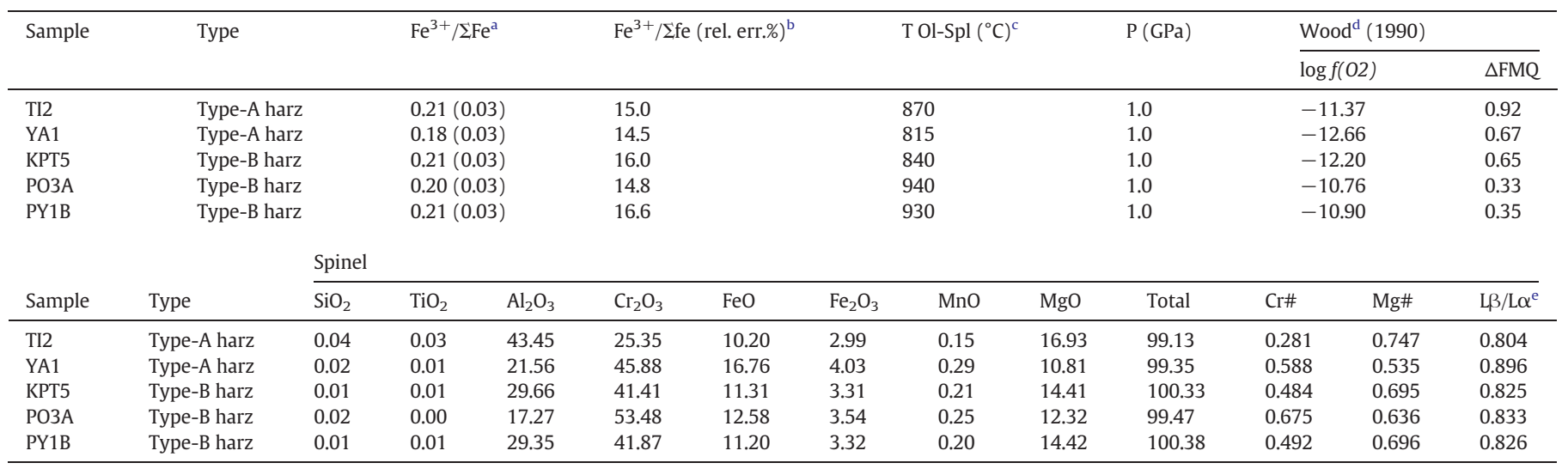

$\mathrm{Fe}^{3+} /\left(\mathrm{Fe}^{2+}+\mathrm{Fe}^{3+}\right)$ ratio has been calculated using the equation: $\mathrm{L} \alpha / \mathrm{L} \beta$ × $0.42+\mathrm{Cr} \#$ x $0.03-\left(\mathrm{FeO}+\left(\mathrm{Fe}_{2} \mathrm{O}_{3} / 1.113\right)\right)$ x 0.01 obtained after standardisation.

a $\mathrm{Fe}^{3+} /\left(\mathrm{Fe}^{2+}+\mathrm{Fe}^{3+}\right)$ in spinel determined by "flank"-method.

b Relative error in \% calculated as a total of measurement errors for $\mathrm{Fe}, \mathrm{Cr}$, $\mathrm{Al}$ and $\mathrm{X}$-ray intensities at flank positions.

c $\mathrm{T}$ Ol-Spl = Equilibration temperature calculated using Li et al. (1995) formulation.

d Oxygen fugacity estimates are from Wood et al. (1990) and are reported as $\Delta \mathrm{log}$ fO2 from the quartz-fayalite-magnetite (FMQ) buffer using the Fe ${ }^{3+} / \Sigma \mathrm{Fe}$ values of the analysed spinels. See text for further details.

e Current normalised ratio of the intensities at flank position for L $\alpha$ and L $\beta$ Fe lines.

pronounced for Au, with the exception of YA1, which displays a negative Pt anomaly. Pd contents are low ( $<0.1$ PM values) and constant for PO4, TI1, TI2, with Pd/Ir showing subchondritic ratios for all the studied samples. Positive correlations are observed between IPGE (Fig. 2a-bc) and Pt-Ir (not shown), and, somewhat surprisingly, between IPGE and the fertility indicators (i.e. $\mathrm{Al}_{2} \mathrm{O}_{3}$ and $\mathrm{CaO}$, not shown). Mass fractions of Te, Se and S are low, often close to or below the detection limit, again with the exception of the harzburgite YA1.

For all type-A harzburgites, Re concentrations are very low (about $0.02 \mathrm{ng} / \mathrm{g}$ ), leading to subchondritic ${ }^{187} \mathrm{Re} /{ }^{188} \mathrm{Os}$ ratios (0.045 to 0.196 , the latter value also reflecting the low Os concentrations in YA1). Os isotopic compositions are subchondritic to chondritic (0.1203-0.1266, corresponding $\left.-5 \leq \gamma_{\mathrm{Osi}(53 \mathrm{Ma})} \leq-0.1\right)$ and do not define any correlation with ${ }^{187} \mathrm{Re} /{ }^{188} \mathrm{Os}$ or incompatible element depletion indices (i.e. $\mathrm{Al}_{2} \mathrm{O}_{3}$, see Fig. 4).

Type- $B$ harzburgites comprise very fresh samples from Kopeto (KPT2, KPT3, KPT5), Poro (PO3) and Poya (PY1) massifs. Compared to type-A harzburgites, these samples have much lower HSE abundances and display variable and strong fractionations Fig. 3 among PGE and more incompatible chalcophile elements (Fig. 2 and 6b). In detail, Os, Ir and Pt show positive correlations (Fig. 2) and are strongly depleted compared to $\mathrm{Ru}, \mathrm{Rh}$ and $\mathrm{Pd}$ (Os = 0.003-0.071 ppb, Ir $=0.015-0.079 \mathrm{ppb}$, with $\mathrm{Os} / \mathrm{Ru}=0.01-0.26$ and $\mathrm{Ru} / \mathrm{Ir}=2.5-20)$. For sample PY1, Pt is enriched relative to IPGE, Rh and Pd (Pt/Rh = 7.7; Pt/Pd = 5.5). Pd, Re and S-Se-Te have similarly low normalised abundances, with chalcophile elements often close to or below the detection limit. Au exhibits positive spikes for PY1, KPT3 and PO3 samples and tends to be more enriched than similar incompatible chalcophile elements (i.e. Pd and Re).

Measured ${ }^{187} \mathrm{Os} /{ }^{188} \mathrm{Os}$ ratios vary from chondritic to suprachondritic (0.1273-0.1534) and are coupled with high and variable ${ }^{187} \mathrm{Re} /{ }^{188} \mathrm{Os}$ (1.62-32). Initial Os isotopic compositions calculated at 53 Ma range from depleted to slightly suprachondritic values (0.1181-0.1365, $\left.-7 \leq \gamma \mathrm{Os}_{(53 \mathrm{Ma})} \leq 3\right)$.

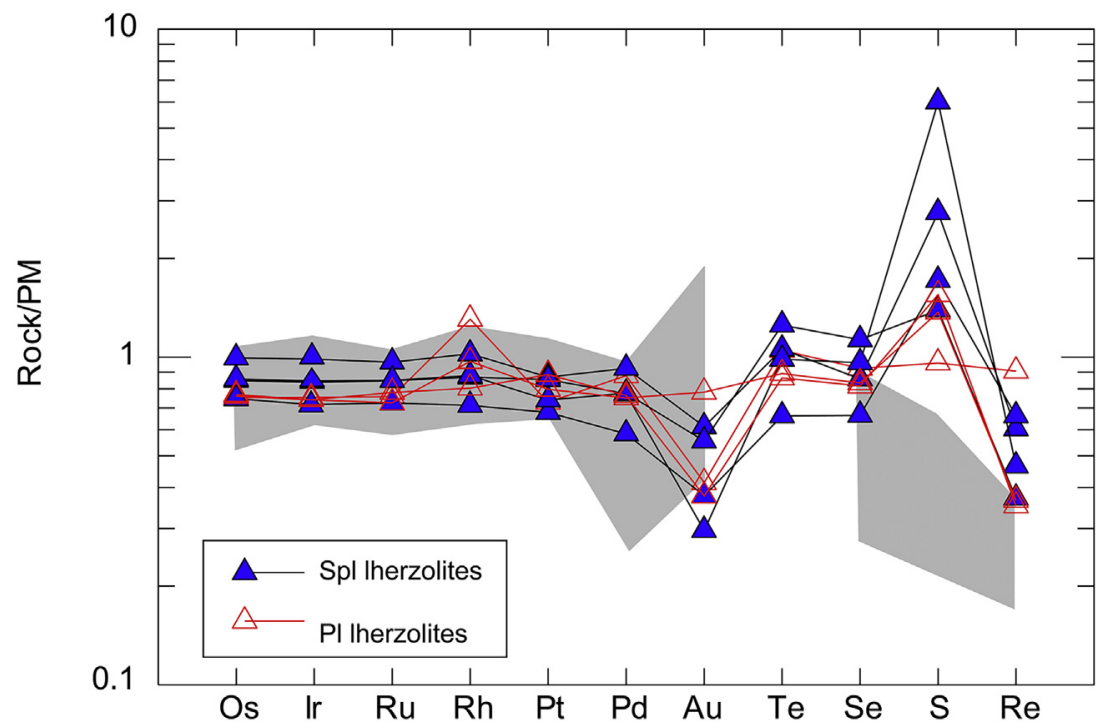

Fig. 3. Primitive mantle normalised HSE and chalcogen patterns for the New Caledonia spinel and plagioclase lherzolites. Grey shaded area includes oceanic lherzolites from Mid-Atlantic and South West Indian ridges (Snow and Schmidt, 1998; Luguet et al., 2001; Luguet et al., 2003) and ophiolitic lherzolites from the Ligurian Units (Fischer-Gödde et al., 2011; Luguet et al., 2004; Snow et al., 2000). Normalising values after Becker et al. (2006), Fischer-Gödde et al. (2011) and Wang and Becker (2013). 

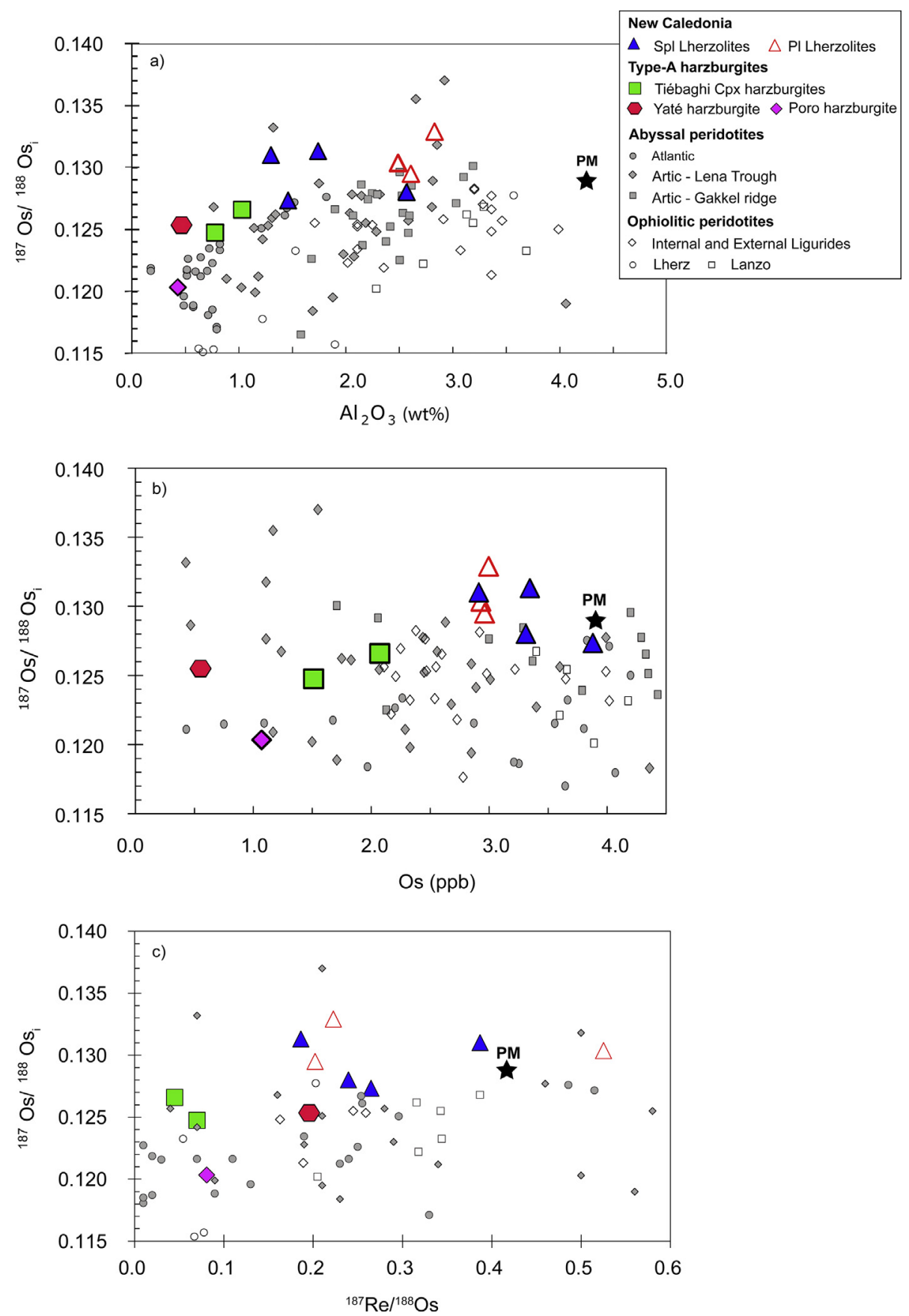

Fig. 4. a) $\mathrm{Al}_{2} \mathrm{O}_{3}$ (wt\%)- ${ }^{187} \mathrm{Os} /{ }^{188} \mathrm{Os} \mathrm{s}_{\mathrm{i}}$ and b) $\mathrm{Os}^{-187} \mathrm{Os} /{ }^{188} \mathrm{Os}$ and c) ${ }^{187} \mathrm{Re} /{ }^{188} \mathrm{Os}-{ }^{187} \mathrm{Os} /{ }^{188} \mathrm{Os}$ diagrams showing data from New Caledonia lherzolites and type-A harzburgites in comparison to PM compositions. PM data from Meisel et al., 1996. Data for abyssal peridotites are from Harvey et al., (2006) for Atlantic peridotites, Lassiter et al., (2014) for Lena through and Liu et al. (2015) for Gakkel ridge. See Fig. 2 for ophiolitic peridotites references.

Replicate analyses of samples PY1, KPT2, KPT5, PO3 yield quite similar results for $\mathrm{Ru}(<5 \%$ relative deviation, except for sample KPT2) and Au ( 6\% for PY1 and KPT5) and acceptable results for Pt for PY1-KPT5 (11.5-14.0\% relative deviation). Values appear much more scattered for Os and Re (RSD > 30\%) and less dispersed for Rh and Pd ( $7 \leq \mathrm{RSD} \%$ $\leq 32$ ). The relative deviation of chalcophile elements is more limited, mostly $<15 \%$.

The large variations of mass fractions of HSE and chalcophile elements in duplicate samples reflects the very low mass fractions of these elements combined with the inhomogeneity in the distribution of HSE carrier phases in gram-size quantities of rock powder, an issue that has already been recognised in peridotitic rocks (e.g. Becker et al., 2006; Luguet et al., 2007).

\subsection{Oxybarometry}

Results for calculations of $f_{\mathrm{O} 2}$ using coexisting olivine, orthopyroxene and spinel (e.g., Wood, 1990, see Table 2 and Table S2) with the reaction are given in Table 2 .

$6 \mathrm{Fe}_{2} \mathrm{SiO}_{4}+\mathrm{O}_{2} \rightarrow 3 \mathrm{Fe}_{2} \mathrm{Si}_{2} \mathrm{O}_{6}+2 \mathrm{Fe}_{3} \mathrm{O}_{4}$

The calculation of $f_{\mathrm{O} 2}$ depends on the pressure and temperature of equilibrium. For this study, we used olivine-spinel geothermometry (Li et al., 1995) as this thermometer is based on the same elements and minerals (Fe and $\mathrm{Mg}$ content in olivine and spinel) that are used to calculate $f_{\mathrm{O} 2}$. As spinel peridotites lack a good barometer, in order 

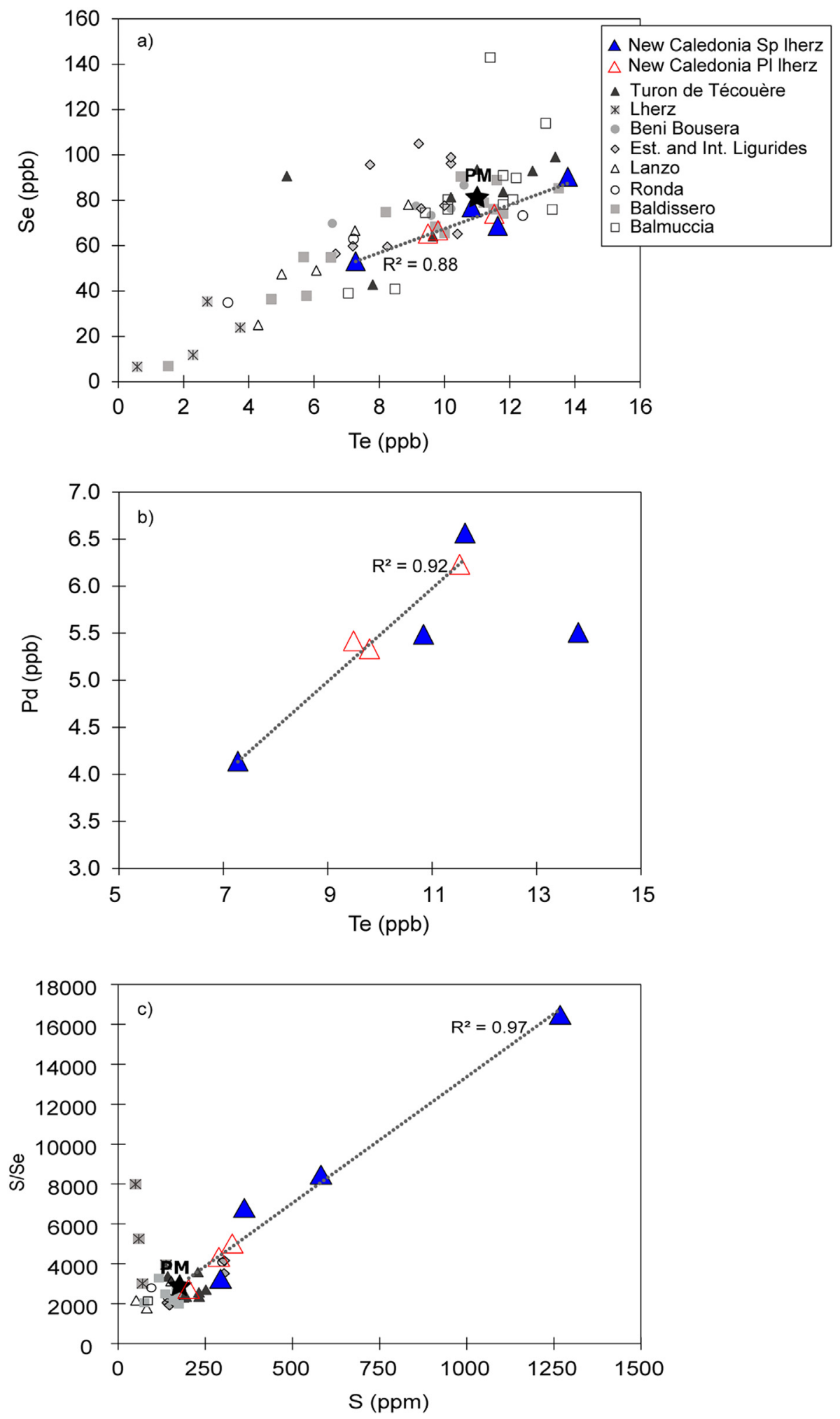

Fig. 5. a) Te vs. Se, b) Te vs. Pd and c) S vs. S/Se correlation diagrams for New Caledonia spinel and plagioclase lherzolites. Data for orogenic lherzolites from Wang and Becker (2013) are also plotted for comparison.

to maximise consistency with temperatures determined with Li et al. (1995) thermometer, we have assumed a pressure of $1.0 \mathrm{GPa}$.

Ferric to total iron ratios $\left(\mathrm{Fe}^{3+} / \Sigma \mathrm{Fe}\right)$ in spinel are similar within the harzburgites, covering a limited range of values $\left(0.18 \leq \mathrm{Fe}^{3+} / \mathrm{Fe}^{3+}+\right.$ $\mathrm{Fe}^{2+} \leq 0.21$, see Table 2 ) indicating similar $f_{\mathrm{O} 2}$ values for the two harzburgite sub-groups $(\triangle \log F M Q=0.35-0.92)$.
In Fig. 7a-b spinel $\mathrm{Cr} \#$ is reported against $\mathrm{Fe}^{3+} / \Sigma \mathrm{Fe}$ ratio and $\triangle \log F M Q$ for the analysed samples. Literature data for mantle peridotites from different geodynamic settings (i.e. MOR and suprasubduction zone) and arc xenoliths have also been plotted for comparison. Overall, the harzburgites share remarkable similarities with suprasubduction zone peridotites from the Izu-Bonin area (Parkinson and 

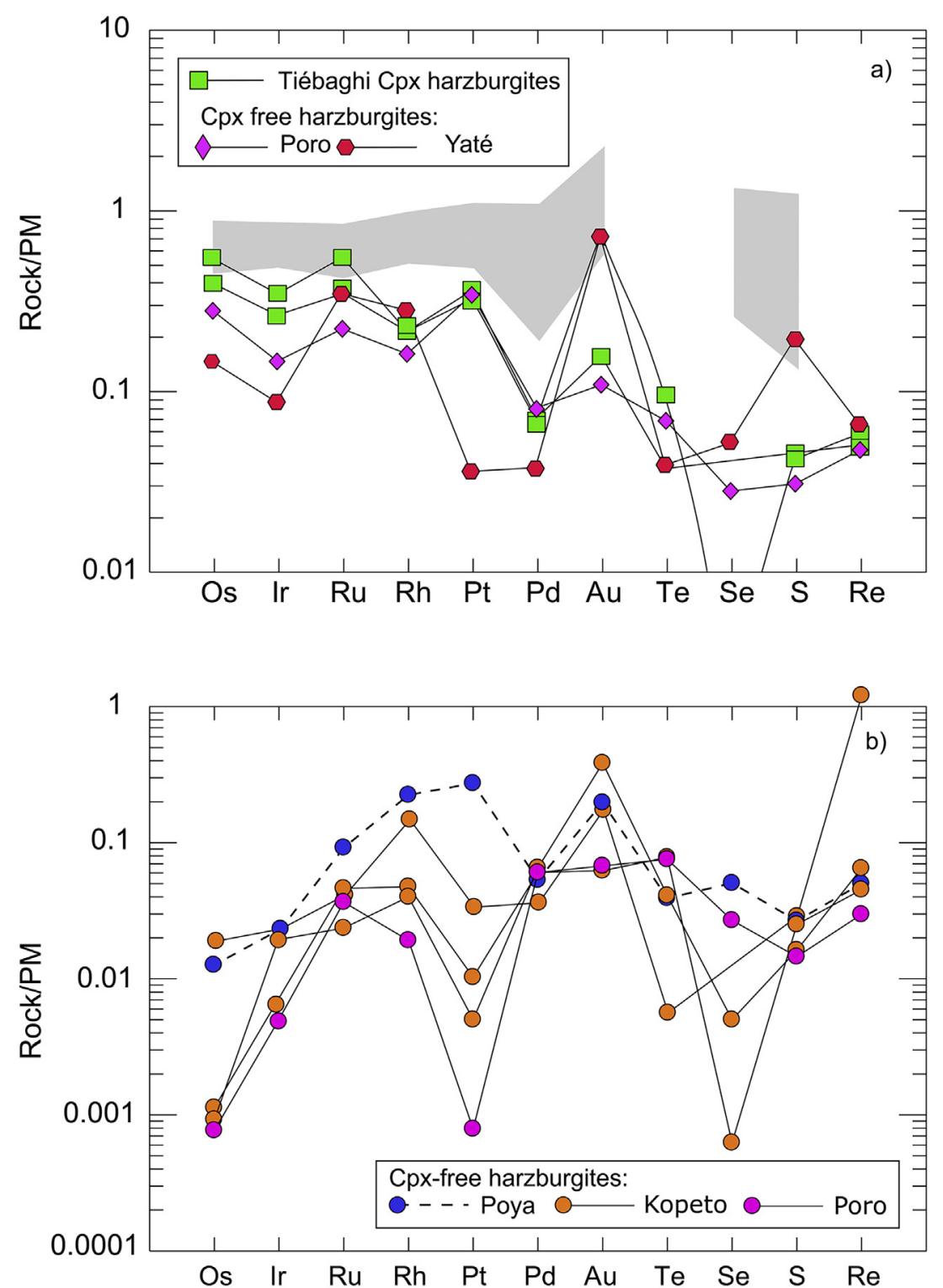

Fig. 6. a) Primitive mantle normalised HSE and chalcogen abundances in type-A harzburgites. Light grey shaded field encompasses the area of modern MOR harzburgites (Snow and Schmidt, 1998; Luguet et al., 2001, 2003; Harvey et al., 2006; Marchesi et al., 2013); b) Primitive mantle normalised diagram showing HSE and chalcogen patterns of type-B harzburgites. Normalising values are after Becker et al. (2006), Fischer-Gödde et al. (2011) and Wang and Becker (2013).

Pearce, 1998). Slightly lower Cr\# values compared to the other harzburgites are displayed by TI2 sample, which in turn falls between abyssal peridotites and arc xenoliths array (Fig. 7a).

\section{Discussion}

\subsection{HSE and Re-Os systematics of the lherzolites}

Major element composition and lithophile trace element chemistry of spinel lherzolites indicate moderately depleted compositions, inherited from moderate partial melting degrees (8-9\%) of a DMM source, whereas plagioclase lherzolites originated through reactive melt percolation of spinel lherzolites by highly depleted, incremental melt fractions of a DMM source in the shallow lithosphere (Secchiari et al., 2016). In the following sections, the processes that may have affected HSE and Os isotopic signature of the New Caledonia lherzolites will be discussed: low temperature alteration, in particular serpentinisation, partial melting and the role of melt infiltration and chemical disequilibrium of the HSE in mantle rocks.

\subsubsection{Effects of serpentinisation on HSE and ${ }^{187} \mathrm{Os} /{ }^{188} \mathrm{Os}$}

Serpentinisation is a widespread process of hydrothermal alteration in ultramafic lithologies. However, its influence on HSE behaviour has not been investigated with much detail, despite some authors have proposed it as a possible cause for ${ }^{187}$ Os ingrowth and Re variations in the upper mantle (Snow and Reisberg, 1995; Standish et al., 2002; Walker et al., 1996). Recent experimental studies have shown that during serpentinisation the formation of secondary sulphides, $\mathrm{Fe}-\mathrm{Ni}$ alloys and native metals $(\mathrm{Au}-\mathrm{Cu})$ is promoted by reducing $f_{\mathrm{O} 2}$ conditions (Klein and Bach, 2009; Foustoukos et al., 2015) and thus, with the exception of Au, HSE may be retained in the host rock. Comparison of partially serpentinised and unserpentinised peridotites displaying similar major element features supports the notion that at least PGE ratios are not significantly affected by moderate to strong serpentinisation (Becker and Dale, 2016).

The New Caledonia lherzolites underwent intermediate serpentinisation degrees ( $\mathrm{LOI}=6.4$ to $10.7 \%$, see paragraph 2.1 and Table 1), which had limited effects on the budget of fluid immobile moderately incompatible lithophile trace elements in these rocks 

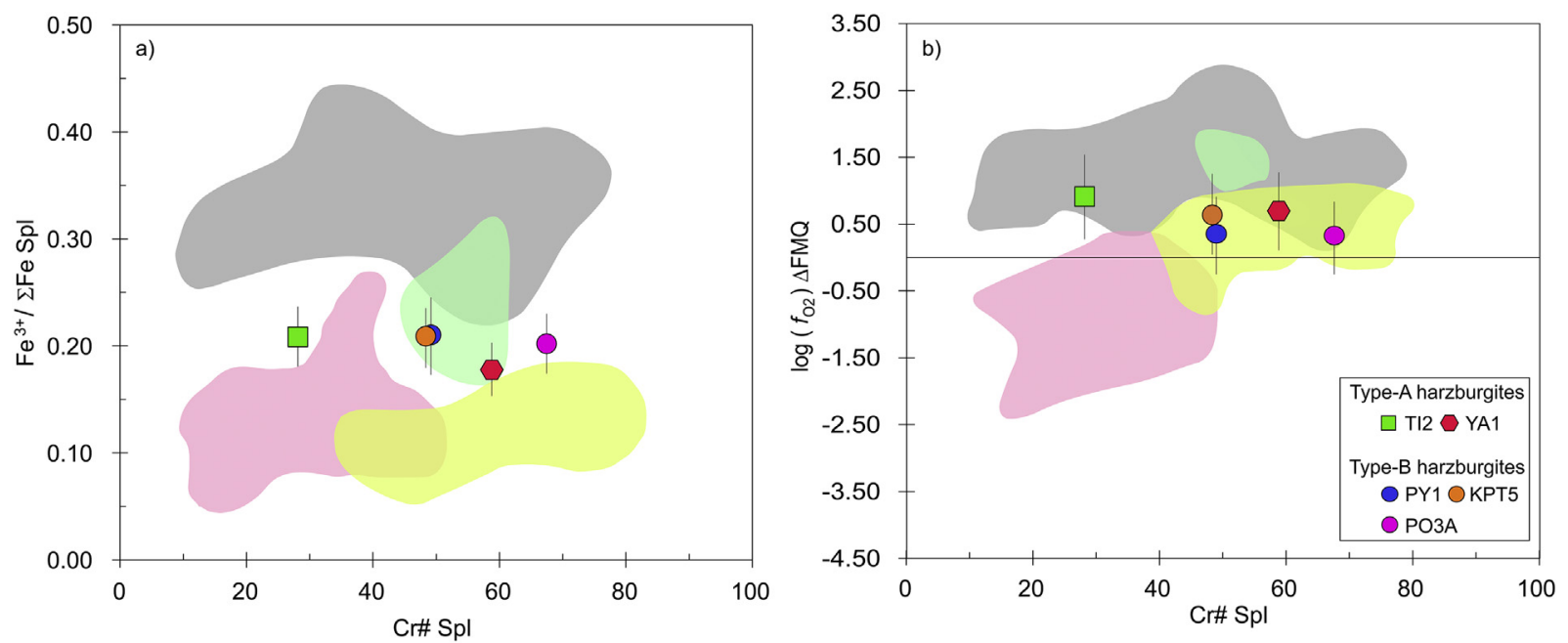

Fig. 7. a) $\mathrm{Fe}^{3+} / \mathrm{\Sigma Fe}$ ratios in spinel and b) $\log \left(f_{\mathrm{O} 2}\right) \Delta \mathrm{FMQ} v \mathrm{Cr} \#$ in spinel for samples from this study. Error bars in a $=$ relative error expressed as $\%$ (see Table 2$)$. Error for log $\left(f_{\mathrm{O} 2}\right) \Delta \mathrm{FMQ}$ includes error related to $f_{\mathrm{O} 2}$ sensor ( $0.5 \mathrm{log}$ units) plus uncertainties derived from $\mathrm{Fe}^{3+}$ /Fetotal ratio measurements (see Table 2). Background fields represent literature data for mantle peridotites: pink = abyssal peridotites (Bryndzia and Wood, 1990); grey = arc xenoliths (Brandon and Draper, 1996; Parkinson et al., 2003; Wood and Virgo, 1989); light green and light yellow = Toroshima and Conical seamount respectively (Parkinson and Pearce, 1998). Modified after Birner et al. (2017). (For interpretation of the references to colour in this figure legend, the reader is referred to the web version of this article.)

(Secchiari et al., 2016). Notably, PGE contents and ratios in the lherzolites are similar to other unaltered and serpentinised lherzolites from the modern oceans and ophiolitic complexes (see Figs. 2 and 3 e.g.; Snow et al., 2000; Luguet et al., 2001, 2004; Pearson et al., 2004; Alard et al., 2005; Becker et al., 2006; Fischer-Gödde et al., 2011; Becker and Dale, 2016). This observation supports the hypothesis that PGE abundances are comparable in fresh and variably serpentinised ultramafic rocks (Becker et al., 2006; Becker and Dale, 2016; FischerGödde et al., 2011; Liu et al., 2009; Marchesi et al., 2013), implying that serpentinisation results in minor changes in PGE ratios.

By contrast, the possible influence of serpentinisation on Au and Re is more difficult to evaluate, as no study has systematically investigated its effect on the behaviour of the aforementioned elements. In the lherzolites from New Caledonia, Au displays similar normalised concentrations as Re and, with the exception of a few samples, both elements are depleted relative to Pd, Te and Se. Au abundances tend to be somewhat lower than abundances in other lherzolites with similar major element composition (Fig. 3). Although the compositions can be entirely explained by magmatic fractionation processes (see subsequent chapters), minor losses of Au due to hydrothermal alteration cannot be ruled out (e.g. Lorand et al., 1999). The lack of correlation with $\mathrm{Al}_{2} \mathrm{O}_{3}$ and $\mathrm{Yb}_{\mathrm{N}}$ (not shown) could be a hint that Au abundances may have been affected by a combination of magmatic processes and serpentinisation (i.e. Fischer-Gödde et al., 2011). Rhenium is slightly depleted compared to the PGE for most of the studied lherzolites, but displays higher concentrations than other mantle lherzolites (Fig. 3). In addition, Re contents do not correlate with $\mathrm{LOI}$ and $\mathrm{Re} / \mathrm{Os}$ ratios cover the range generally reported for moderately depleted mantle rocks. The samples with the lowest Re contents display the highest LOI values, suggesting that no significant quantities of Re were added during the interaction with seawater during serpentinisation, as also supported by the chondritic to subchondritic ${ }^{187} \mathrm{Re} /{ }^{188} \mathrm{Os}$ ratios (see Table 1 ).

Likewise, the chondritic to slightly suprachondritic ${ }^{187} \mathrm{Os} /{ }^{188} \mathrm{Os}$ cannot be ascribed to serpentinisation, as unrealistically high water-rock ratios $\left(\sim 10^{3}-10^{4}\right)$ would be required in order to perturb the whole rock ${ }^{187} \mathrm{Os} /{ }^{188}$ Os at the \% level or higher (e.g. Becker and Dale, 2016). The lherzolite data also show mass fractions of Se and Te and Se/Te that are similar to values in unserpentinised lherzolites (e.g., Wang and Becker, 2013). In contrast, sulphur in most lherzolites from New Caledonia shows much higher concentrations than typical for peridotites, which is readily explained by contamination with seawaterderived sulphur during serpentinisation.
We thus conclude that the HSE (perhaps with the exception of $\mathrm{Au}$ ), $\mathrm{Se}$, Te and Re-Os signature of the lherzolites offer no evidence to support that serpentinisation and associated reactions affected these elements in a noticeable way.

5.1.2. Partial melting and chemical disequilibrium of the HSE in the mantle Spinel and plagioclase lherzolites exhibit comparable HSE contents and patterns, similar to other lherzolites from oceanic or continental settings that underwent low to moderate degrees of melt extraction (Figs. 2 and 3).

Partial melting has often been invoked as a possible cause for HSE and ${ }^{187} \mathrm{Os} /{ }^{188} \mathrm{Os}$ variations in mantle rocks (e.g. Meisel et al., 2001; Reisberg and Lorand, 1995). Studies of the behaviour of HSE during mantle melting and their abundances in mantle rocks have supported the hypothesis that HSE concentrations in residual peridotites result from sulphide-silicate partitioning during magmatic processes (i.e Becker and Dale, 2016; Brenan et al., 2016 and references therein). Experimental studies have also highlighted that at temperatures relevant for mantle processes sulphide liquid and, in special cases, sulphide solid solutions, coexist in equilibrium with silicate melt, olivine, pyroxenes and an Al-rich phase (e.g. Brenan et al., 2016; Mungall and Brenan, 2014; Rehkämper et al., 1999). Experimentally determined sulphide melt-silicate melt partition coefficients $\left(D^{\text {sulph/sil }}\right)$ for PGE have been shown to be high and constant $\left(10^{5}\right.$ to $10^{6}$, e.g. Mungall and Brenan, 2014; Brenan et al., 2016), while Au shows slightly lower $D^{\text {sulph/sil }}$ $\left(\sim 10^{4}\right)$. Therefore, up to moderately high degrees of melting, PGE behave as compatible elements and their inter-elemental ratios remain similar as long as sulphide is present in the mantle residue (i.e. until $20-25 \%$ of partial melting, depending on initial S content of the source, see Fonseca et al., 2011; Mungall and Brenan, 2014). By contrast, Re is much less chalcophile ( $D^{\text {sulph/sil }} \sim 300-800$, e.g. Fonseca et al., 2007) and is expected to become more quickly depleted in the residual mantle.

Major element compositions of the sulphide phase observed in the spinel lherzolites (Table S1) are consistent with a residual origin after incongruent melting processes (e.g. Bockrath et al., 2004; Ballhaus et al., 2006). The occurrence of homogeneous monosulphides also suggests relatively high cooling rate after the melting event.

Overall, the studied lherzolites are characterised by flat to gently sloping PGE patterns, with similar PM-normalised abundances, no PPGE fractionation and nearly constant ratios for IPGE (i.e. Os/Ir, Ru/ Ir). By contrast, Au and Re display the strongest depletion. These 
features imply that HSE, with the exception of Au and Re, exhibit a similar compatible behaviour during mantle melting, as expected for low to moderate melting degrees in presence of residual sulphide melt. This observation is consistent with the previous estimates obtained through geochemical modelling (Secchiari et al., 2016) and with the occurrence of a residual subsolidus sulphide assemblage in spinel lherzolites.

Although the PGE patterns are nearly flat, with only slight depletion of Pd in a few samples, the depletion of Au and Re, the range of chondritic to slightly suprachondritic $\gamma^{187} \mathrm{Os}_{\mathrm{i}}$ and the higher mass fractions of Se and Te compared to Re and the other HSE suggest a multi-stage history of the lherzolites. Notably, $\gamma^{187} \mathrm{Os}_{\mathrm{i}}$ do not correlate with mass fractions of incompatible HSE such as Re, Re/Os nor with fertility indicators (Fig. 4), as was observed in some other suites of lherzolites (Becker and Dale, 2016).

The Os isotopic signature may be a pre-existing feature of the mantle source, i.e. already present before the recent melt extraction event (Secchiari et al., 2016), as supported by the dispersed Os isotopesfertility indicators trends. In addition, the remarkable absence of magmatic Cu-Fe-rich sulphides (e.g. see Lorand et al., 2003) argue against a recent, post-melting sulphide addition. We thus speculate that the bulk HSE, Se, Te and Os isotope compositions of the lherzolites are the result of partial melting event which affected a mantle source previously characterised by an heterogeneous sulphide population including both residual and magmatic sulfides precipitated along grain boundaries by infiltrating melts (Burton et al., 1999; Lorand et al., 1999; Alard et al., 2000; Alard et al., 2002)

\subsection{Sulphur, Se and Te behaviour in the New Caledonia lherzolites}

Sulphur mass fractions are variable in the lherzolites from New Caledonia and typically much higher compared to estimates of the depleted MORB mantle source (DMM 150-200 ppm, Mathez, 1976; Salters and Stracke, 2004) and unaltered lherzolites (e.g., Wang and Becker, 2013). In addition, sulphur does not correlate with fertility indicators (i.e. $\mathrm{Al}_{2} \mathrm{O}_{3}$ ), as commonly observed in unserpentinised mantle tectonites (e.g., Lorand and Alard, 2010; Wang and Becker, 2013). The high $S$ concentrations and the lack of correlation with melting indicators suggest that $\mathrm{S}$ experienced a late addition during the evolution of these rocks. Sulphur budget of mantle peridotites can be strongly affected by seawater-rock interaction, because of the high sulphate content of seawater, leading to precipitation of hydrothermal sulphides and sulphate (Alt and Shanks, 1998). We note that the major element chemistry indicates a residual origin for the sulphide phases of the lherzolites (see paragraph 4.1 and 5.1.2). Hydrothermal sulphides or sulphates were not identified during microprobe analyses.

Recent geochemical works have demonstrated the role of serpentine as a sink of $S$ under various oxidation states $\left(S^{2-}, S^{-}, S^{0}\right.$ and $S^{6+}$, Debret et al., 2017). These studies have shown that $S$ concentrations can be anomalously high in serpentinised peridotites (up to $1 \mathrm{wt} \%$, see Alt and Shanks, 2003), as S can be accommodated in serpentine minerals, accounting from 60 to $100 \%$ of the sulphur budget of the peridotite (Debret et al., 2017). In situ XANES analyses have also revealed that $S$ can be hosted in nano-phases associated with serpentine or trapped either via Si substitutions in the tetrahedra, or as a sulphate ion in the network of the tetrahedral sheet of serpentine minerals (Debret et al., 2017).

The addition of $\mathrm{S}$ during serpentinisation is also reflected in the high suprachondritic S/Se ratios (up to 16,500) and the excellent correlation observed between $\mathrm{S}$ concentrations and S/Se ratios (see Fig. 5c). Despite the strong S enrichments, Se and Te display 'normal' concentrations and $\mathrm{Se} / \mathrm{Te}$ ratios are in the range of other lherzolites (see Wang and Becker, 2013). These data confirm that Se-Te contents and ratios were not significantly impacted by serpentinisation, as previously observed for other peridotites that experienced low to moderate serpentinisation degrees (e.g. Marchesi et al., 2013; Wang and Becker, 2013).
Moreover, Se-Te show a good correlation between each other (Fig. 5a), implying that they are controlled by the same mineral phases. In mantle peridotites, Se can replace $S$ as a chalcogen anion within the crystalline structure of sulphides (e.g. Bulanova et al., 1996; Hattori et al., 2002; Helmy et al., 2010) or can form Se-rich micro phases, while Tellurium, owing to its semi metal nature, tends to partition between sulphides and late exsolved micrometric tellurides (Pt, Pd, Te, As, Bi phases). The latter are thought to crystallise at low temperatures during cooling, once sulphide melt becomes saturated with respect to Te (Lorand et al., 2008; Lorand and Alard, 2010; Luguet et al., 2004). In the lherzolites, Se and Te do not correlate with melting indicators, but Te displays a rough positive correlation with Pd (Fig. 5b), which suggests that the sulphide melt-bulk silicate partition coefficient of Te should be between Se and Pd (e.g., Figs. 3, 4, 5).

\subsection{Type-A harzburgites: highly siderophile element systematics of a resid- ual sub-arc mantle section}

The distinct HSE patterns and Os isotopic signature testify that the New Caledonia harzburgites recorded a different evolution compared to the northern lherzolites.

Three of the four samples belonging to the sub-group A (TI1, TI2, PO4) show similar HSE patterns and chalcophile elements depletion, suggesting that the same processes contributed to the HSE and chalcophile element budget of these rocks. The low chalcophile element concentrations, close to or below the detection limit, coupled with low $\mathrm{Pd} / \mathrm{Ir}$ ratios and subchondritic ${ }^{187} \mathrm{Os} /{ }^{188} \mathrm{Os}_{\mathrm{i}}$, point out that type-A harzburgites are residues after high degree of melt extraction, where sulphides melts must have been nearly completely dissolved in the coexisting silicate melt.

Experimental studies have predicted a compatible behaviour for all the PGE during mantle melting as long as the sulphide phase is retained in the peridotite (Mungall and Brenan, 2014). Depending on the initial S content of the mantle rocks, $\sim 17-20 \%$ of melting is required for sulphide exhaustion (Fonseca et al., 2011; Mungall and Brenan, 2014). As melting proceeds, sulphides are progressively dissolved into the melt and the PGE concentrate in the residual sulphide melt (Mungall and Brenan, 2014). Assuming that chemical equilibrium is reached, subsequent melt increments should lead to a slightly increase of whole rock PGE contents, leaving elemental ratios almost constant. At the point when sulphide is completely removed, IPGE and Pt are accommodated in metallic alloys, while Re, Au and Pd mass fraction should become extremely low, as these elements are not hosted in any residual mantle phase (Mungall and Brenan, 2014). Hence, for high melting degrees, HSE abundances in the residue should reflect mineral-melt partitioning and the P-T and $\mathrm{f}_{\mathrm{O} 2}$-dependent solubility of Pt and IPGE alloys in silicate melt (Brenan et al., 2016; Fonseca et al., 2011, 2012; Mungall and Brenan, 2014).

The IPGE-PPGE fractionation and the resolvable fractionations between specific PGE displayed by the type-A harzburgites bear witness of high melt extraction degrees, which resulted in the formation of a $\mathrm{S}$-free mantle residue. The fractionated Os-Ir-Ru-Rh segments in the HSE patterns and the positive Pt anomalies are likely carried by tiny residual sulphides (i.e. laurite) and metallic alloys (Os-Ir and Pt—Ir, see Lorand et al., 1999; Luguet et al., 2001, 2007). These latter are thought to precipitate from sulphide melt shortly before the complete exhaustion of sulphide (Mungall and Brenan, 2014) or immediately after sulphide consumption, due to $f_{\mathrm{S} 2}$ lowering and diminished metalsulphide complexation in the silicate melt (Fonseca et al., 2012). The variable but broadly systematic IPGE inter-elemental fractionation (high $\mathrm{Os} / \mathrm{Ir}, \mathrm{Ru} / \mathrm{Ir}$ and $\mathrm{Ru} / \mathrm{Rh}$ ) and the occurrence of positive Pt anomalies possibly suggest the presence of different residual Ir-Pt alloy proportions and preferred Os-Ru retention compared to Ir in the residual PGE alloys (e.g. Brenan and Andrews, 2001; Fonseca et al., 2012). 
The HSE fractionations observed for type-A harzburgites are different from HSE patterns of modern harzburgites in MOR environments (Fig. 6a), as the latter are characterised by flat or weakly-fractionated Os-Ir-Ru triplet, rarely displaying positive Pt spikes (Snow and Schmidt, 1998; Luguet et al., 2001, 2003). By contrast, HSE elemental fractionations of type-A harzburgites resemble those observed for some arc xenoliths (Liu et al., 2015; Saha et al., 2005; Scott et al., 2019) or ophiolitic peridotites bearing a supra-subduction zone affinity (see Büchl et al., 2004, 2002; O'Driscoll et al., 2012). Notably, similar HSE fractionations have also been reported for mantle xenoliths from the Chatam Islands (New Zealand, see Pearson et al., 2004).

Accordingly, trace element geochemical modelling has shown that the extreme depletion in trace element contents displayed by the New Caledonia harzburgites was achieved through a polyphase evolution, including a first melting event in a mid-ocean ridge setting, followed by fluid-assisted melting reaching clinopyroxene exhaustion in a subduction system (see Secchiari et al., 2020). Such high melting degrees are permissible in supra-subduction zone environments, where hydrous conditions at relatively low pressures can produce melt fractions substantially exceeding $20 \%$ without invoking extremely high temperature (e.g. see Ulmer, 2001). In addition, LREE and FME (Sr, $\mathrm{Ba}, \mathrm{Pb}$ ) enrichments coupled with variable $\mathrm{Pb}$ isotope compositions of the type-A harzburgites may be explained by syn- and postmelting interactions with different subduction-related components (i.e. aqueous fluids and melts originated in the forearc setting, see Secchiari et al., 2019, 2020).

We thus conclude that the HSE and chalcophile element signature displayed by TI1, TI2 and PO4 predominantly reflect high degrees of melt extraction in a supra-subduction zone environment. The positive Pt spikes suggest that Pt-rich alloys were stable in the mantle residue and were only in part dissolved in the melt during melt extraction.

The enrichments of Au are modest $(0.2-1.3 \mathrm{ng} / \mathrm{g} \mathrm{Au})$ and may be related to fluid overprint, either from slab-derived fluids (Kepezhinskas et al., 2002; McInnes et al., 1999) or from low-T alteration, e.g. during obduction (e.g. Snow et al., 2000).

The harzburgite YA1 shows higher S and Se concentrations (Fig. 5a), which, considering the significant LOI value of $6.83 \mathrm{wt} \%$, could be related to serpentinisation and precipitation of secondary sulphides. The strongly fractionated HSE pattern and the low concentrations of the incompatible HSE (i.e. Pd, Re) indicate that the HSE budget of YA1 is also governed by melting, as for TI1, TI2 and PO4 harzburgites. The low Os, Ir and Pt concentrations, are much closer to the values reported for type-B harzburgites (see Table 1 and Fig. 5b). Sample YA1 can thus be seen as transitional between type-A and type-B sub-group.

5.4. Origin of type-B harzburgites - strong depletion followed by subduction zone metasomatism?

Type-B harzburgites mostly occur in the central massifs, however one sample (PO3) has also been identified in the eastern zone, close to the area where one type-A harzburgite (PO4) was sampled. Type-B harzburgites display remarkably different HSE and Re/Os behaviour compared to type-A sub-group (Figs. 2 and 6).

Type-B harzburgites show low abundances of incompatible chalcophile elements, i.e. Pd, S, Se and Re, with values in the range of type-A harzburgites. In principle such low concentrations could be reconciled with high melting degrees and sulphide exhaustion in the mantle source. The strong depletion of Os, Ir and Pt, (Fig. 6b) coupled with slightly subchondritic to suprachondritic ${ }^{187} \mathrm{Re} /{ }^{188} \mathrm{Os}(0.23$ to 37 ) and ${ }^{187} \mathrm{Os} /{ }^{188} \mathrm{Os}(0.1239$ to 0.302$)$ are remarkable and do not occur in residual harzburgites from convecting mantle, as represented by abyssal peridotites. By contrast, type-B harzburgites share some similarities with mantle xenoliths from arc settings, such as low Os contents associated with chondritic to suprachondritic ${ }^{187}$ Os/ ${ }^{188}$ Os (Brandon et al., 1996, 1999; Saha et al., 2005; Widom, 2011). These features have been ascribed to interactions with subduction zone fluids (i.e. fluids from subducted altered oceanic crust and/or its sedimentary cover), which may have induced sulphide breakdown, locally overprinting the Os isotopic signature of the mantle (Widom et al., 2003). Such qualitative observations have also been supported by experimental works, that highlighted the critical influence of oxygen fugacity $\left(f_{\mathrm{O} 2}\right)$ on sulphide and alloy stability (e.g. Andrews and Brenan, 2002; Fonseca et al., 2011, 2012; Mungall and Brenan, 2014). In addition, the strongly fractionated, IPGE-depleted, HSE patterns of the type-B harzburgites closely resemble those observed in some refractory harzburgites and replacive dunites from ophiolitic complexes that underwent interaction with Sundersaturated melts (Büchl et al., 2002; Lorand et al., 2004).

As metasomatism by subduction fluids and hydrous melts has been proposed for the New Caledonia harzburgites based on isotopic and incompatible element studies, we have determined oxygen fugacities on a set of five harzburgites, in order to test if the HSE signature of the two sub-groups could reflect different oxygen fugacity conditions.

As a whole, the harzburgites in our dataset bear witness of similar oxygen fugacity conditions, showing no significant difference among sub-types A and B. Both groups register oxygen fugacity values close to or only slightly higher than the FMQ buffer, displaying a nearly horizontal trend in the Cr\# vs $\log \left(f_{\mathrm{O} 2}\right) \triangle \mathrm{FMQ}$ variation diagram (Fig. 7b).

Partial melting of a spinel peridotite source is expected to induce progressive $\mathrm{Fe}^{3+} / \Sigma \mathrm{Fe}$ lowering in the residual mantle, due to the preferential removal of $\mathrm{Fe}^{3+}$ in Al-rich spinel and clinopyroxene during melt extraction (Woodland et al., 2006). Thus, as melting proceeds and the aforementioned phases are removed from the mantle assemblage, melt extraction in un-buffered conditions should result in $f_{\mathrm{O} 2}$ lowering in the residual mantle, generating negative $\mathrm{Cr} \#$ vs. $\log \left(f_{\mathrm{O} 2}\right) \Delta \mathrm{FMQ}$ trends (e.g. Brandon and Draper, 1996). However, these correlations are rarely preserved in mantle peridotites, as subsequent geochemical modifications, e.g. metasomatism, tend to decouple $f_{\mathrm{O} 2}$ from melting depletion indexes. In particular, in the sub-arc region, interaction of the refractory peridotite with subduction components is expected to shift the oxygen fugacity state towards higher values, due to the high oxidation capacity of slab-derived fluids and melts (e.g. Parkinson and Arculus, 1999; Brandon and Draper, 1996; Parkinson et al., 2003).

The subhorizontal trends observed in Fig. 7a-b, as well as the slightly oxidised $f_{\mathrm{O} 2}$ values, thus bear evidence that oxygen fugacity was modified during melting and/or post-melting evolution of the New Caledonia harzburgites. The measured $f_{\mathrm{O} 2}$ are similar to those observed for the less oxidised peridotites from the Izu-Bonin region, plotting at the lower end of the arc xenoliths domain (see Fig. 7b; Wood and Virgo, 1989; Brandon and Draper, 1996; Parkinson et al., 2003). Such oxygen fugacity values most likely reflect limited interaction with slab-derived fluids and melts, in agreement with the geodynamic scenario proposed for the New Caledonia archipelago and the previous geochemical models (see Secchiari et al., 2020). In fact, Eocene subduction is believed to have started close to or in correspondence of an active oceanic spreading center, where hot and young ( 6-9 My old, Cluzel et al., 2016) lithosphere was forced to subduct. In such a context, fluid fluxes from the downgoing slab must have been limited, due to the young age of the subducted material and the intra-oceanic nature of the subduction (Cluzel et al., 2016). In addition, post melting metasomatism involved small fractions $(0.5-1 \%)$ of depleted (boninitic) melts, which may have not been able to shift mantle oxidation state towards more oxidised conditions. In fact, while large oxygen fugacity variations in mantle peridotites are permissable for low $\mathrm{Fe}^{3+}$ contents in spinel, more and more $\mathrm{Fe}^{3+}$ has to be added to cause even a small increase in $f_{\mathrm{O} 2}$ when $f_{\mathrm{O} 2}$ approaches FMQ buffer (Woodland et al., 2006).

The similar $f_{\mathrm{O} 2}$ values registered by the two harzburgite sub-types attest that HSE behaviour was not critically influenced by different oxygen fugacity conditions. This observation supports the hypothesis that the two types of patterns are not directly linked to a specific process (i.e. higher melt extraction or enrichment degree or interaction with an oxidised component). Rather, the occurrence of two distinct patterns in the harzburgites may reflect an effect of source-control on the HSE 
behaviour during the recent evolution, indicating the presence of geochemically heterogeneous mantle domains below the New Caledonia archipelago before Eocene subduction.

\subsection{Type-B harzburgites: a broader perspective}

Despite being similar in terms of chemistry or mineralogy, type-A and B harzburgites possess distinct HSE signatures. In addition, the HSE signatures of type-B harzbugites have not yet been identified in other mantle tectonites, either from modern oceanic lithosphere or ophiolitic complex.

However, similar compositions have been recently reported for some moderately depleted to highly refractory peridotites and mantle xenoliths from New Zealand (Scott et al., 2019). The New Zealand mantle is composed of isotopically heterogeneous mantle fragments with evolutionary histories extending over $2.75 \mathrm{Ga}$ (Os model ages = 0.1-2.75 Ga, with a broad peak at $1.2 \mathrm{Ga}$ ), and PGE systematics decoupled from major element compositions (see Liu et al., 2015; Scott et al., 2019). These features have been explained by accretion of Zealandia lithospheric mantle from amalgamation of genetically unrelated convecting mantle fragments which were swept together beneath the Gondwana subduction margin, variably re-melted and laterally accreted (Scott et al., 2019).

Among the New Zealand peridotite suites, mantle xenoliths from Lake Moana and Chatam Island show HSE patterns that are similar to our dataset (Fig. 8). Lake Moana Cretaceous xenoliths include cpxfree harzburgites that experienced up to 30\% melting, while Eocene-aged Chatam Island harzburgites exhibit a less refractory nature, as attested by the presence of primary clinopyroxene (up to $1.8 \%$ modal, Scott et al., 2016). Such depletion degrees were achieved either by plume melting or hydrous melting in an arc setting for the Lake Moana xenoliths, whereas Chatam Island samples are thought to represent fragments of fore-arc lithophere (Scott et al., 2016, 2019).

Overall, HSE diagrams highlight that New Zealand mantle xenoliths reproduce with good approximation both patterns observed in our harzburgites, namely type-A and type-B (Fig. 8). IPGE patterns are broadly sub-parallel, with the New Caledonia harzburgites falling within or at the lower range of values displayed by the New Zealand samples, whereas Pt, Pd and Re exhibit greater variability.
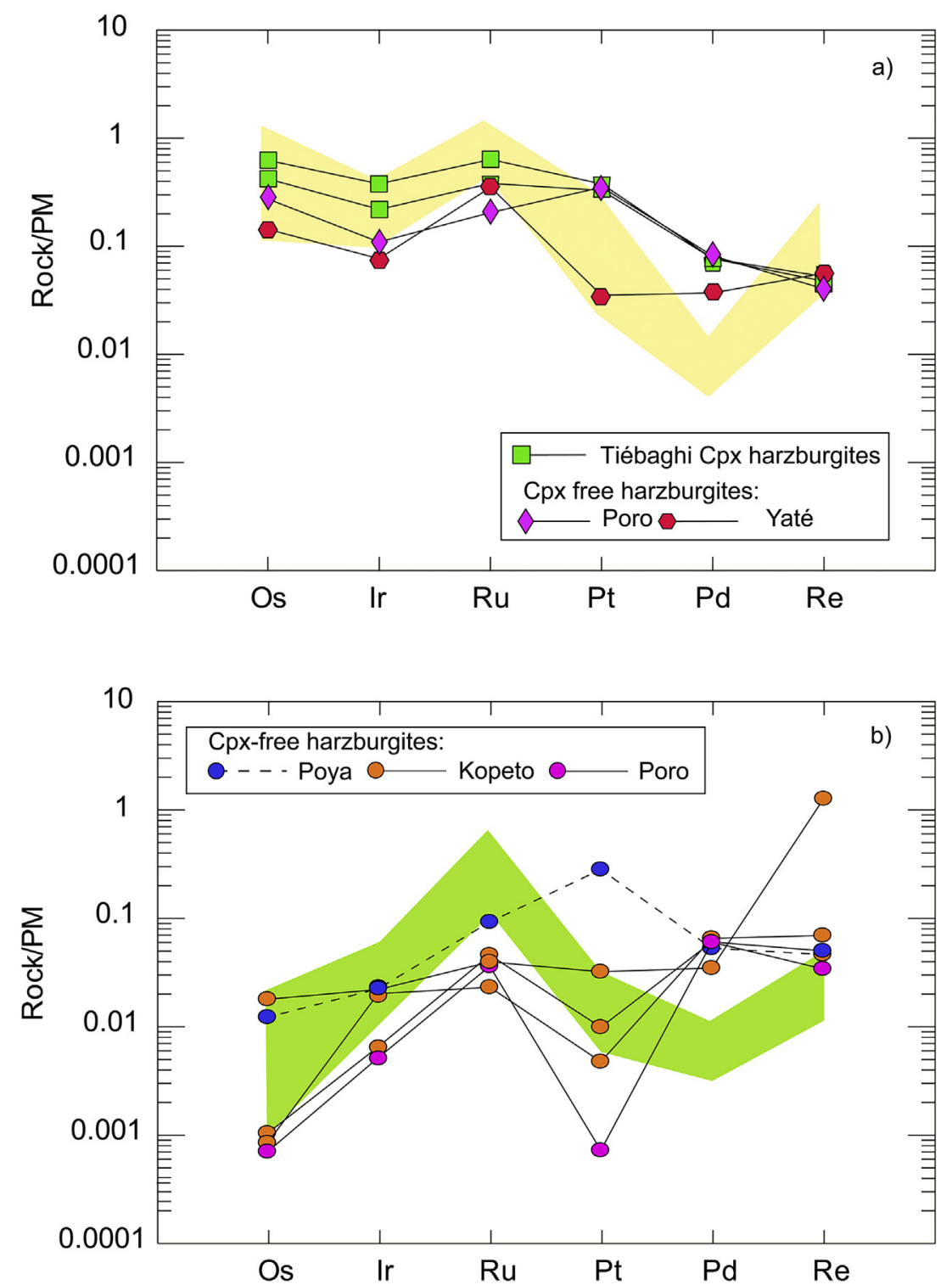

Fig. 8. Primitive mantle normalised HSE abundances of a) type-A and b) type-B harzburgites compared to the HSE composition displayed by New Zealand mantle xenoliths (Scott et al., 2019). See text for further detail. 
For most of the New Zealand xenoliths, Ru concentrations are higher compared to the contents in the New Caledonia harzburgites. Higher Ru contents cannot be ascribed to different degrees of melting, as fertility indicators (i.e. $\mathrm{Mg} \#(\mathrm{Ol}), \mathrm{Cr} \#(\mathrm{Spl}))$ indicate comparable depletion degrees for both peridotite suites (see Scott et al., 2016, 2019; Secchiari et al., 2020). The increased Ru retention in the New Zealand samples may be reconciled to the higher $\mathrm{Cr}$-spinel content of these lithologies (up to $2.8 \%$, see Scott et al., 2016, vs. up to $0.8 \%$ for our harzburgites). Numerous studies have in fact demonstrated that spinel can be a significant host for Ru ( $D^{\text {spinel/melt }} \sim 20$, Capobianco and Drake, 1990). In addition, increase in oxygen fugacity markedly enhances Ru compatibility in Cr-rich spinel ( $\mathrm{D}^{\text {spinel/melt }}$ up to 500 for $f_{\mathrm{O} 2}$ of $-0.5 \mathrm{FMQ}$ Park et al., 2012), which can accomodate Ru within its crystal lattice (Pagé and Barnes, 2016) or as laurite and/or Ru-rich alloy inclusions (Brenan and Andrews, 2001). Recent geochemical works have also illustrated the importance of Ru retention in the sub-arc mantle for the HSE signature of arc lavas (Dale et al., 2012; Park et al., 2013). These studies explain the low Ru concentrations and the high Pt/Ru ratios of the volcanic products as related to Ru retention in the mantle source due to the presence of $\mathrm{Cr}$ rich spinel or PGM (see Dale et al., 2012; Park et al., 2013). Likewise, positive Ru anomalies in our type-B harzburgites may reflect the presence of small laurite or Ru-rich phase inclusions, which could have escaped the high melting degrees due to the shield effect of spinel.

Other HSE (e.g. Pd and Re) in the New Caledonia harzburgites display a wider range of values compared to the New Zealand samples. Enrichments in Pd have also been recognised in other sub-arc mantle sections, where they have been attributed to slab-derived fluids metasomatism, due to the high solubility of Pd in aqueous fluids (McInnes et al., 1999; Park et al., 2013). Likewise, Re addition in mantle wedge peridotites may be due to Re release in slab derived fluids during dehydration of the mafic portion of the subducting slab (see Dale et al., 2009). Hence, we conclude that Pd-Re (as well as Te-Se-S) re-enrichments in type-B harzburgites may have been facilitated by minor sulphide precipitation from slab-derived fluids or melts.

By contrast, the widespread negative Pt anomalies may reflect destabilisation of a pre-existing Pt-alloy phase, possibly related to melting after alloy saturation (see Mungall and Brenan, 2016), and Pt release into the melt.

\subsection{Inferences from Re-Os systematics of the New Caledonia harzbugites}

All type-A harzburgites, including YA1, show unradiogenic ${ }^{187} \mathrm{Os} /{ }^{188} \mathrm{Os}_{\mathrm{i}}$ and very low $\mathrm{Re} / \mathrm{Os}$ relative to the range of chondritic values (Walker et al., 2002) or primitive mantle estimates (Meisel et al., 1996). The $\gamma_{\text {osi }}$ overlap with data from depleted abyssal peridotites and mantle sections from some ophiolites (e.g., Becker and Dale, 2016).

In order to obtain an estimate of the time of melt depletion, we calculated Re-Os model ages $\left(\mathrm{T}_{\mathrm{MA}}\right)$ and Re-depletion model ages $\left(\mathrm{T}_{\mathrm{RD}}\right)$. $T_{R D}$ is generally used to estimate model ages of mantle peridotites that experienced high degrees of melt extraction, leading to low Re contents and low Re/Os ratios. For mantle peridotites which are pure residues of high partial melting degrees sufficient to remove all Re, then $\mathrm{T}_{\mathrm{MA}}$ and $\mathrm{T}_{\mathrm{RD}}$ ages should be identical. If a minor amount of Re remains, the two values should be relatively similar, with $\mathrm{T}_{\mathrm{RD}}$ providing a minimum depletion age.

The Re-depletion ages for type-A harzburgites are quite homogeneous for three of our samples (TI1, TI2, YA1) ranging between 0.4 and $0.7 \mathrm{Ga}$ (see Table 1), while sample PO4 yields an older Redepletion age of $1.3 \mathrm{Ga}$. Slightly older ages are provided by $\mathrm{T}_{\mathrm{MA}}$ (0.5-1.0 Ga for TI1, TI2, YA1 and 1.5 Ga for PO4), indicating that Re was not effectively removed after partial melting.

The younger model ages recorded by the harzburgites are likely linked to the evolution of the New Caledonia mantle in relationship to the eastern Australian margin, from which the New Caledonia archipelago was separated via marginal rifting about $90 \mathrm{Ma}$ ago (Cluzel et al.,
2001, 2012; Whattam, 2009). The ancient Re depletion age of the harzburgite $\mathrm{PO} 4$, on the other hand, reflects a mantle domain characterised by long-term low Re/Os ratio. This age is also mirrored by $\mathrm{Nd}$ isotopic signature, which shows a highly radiogenic value $\left(\varepsilon_{\mathrm{Ndi}}=\right.$ +13.32 , Secchiari et al., 2020), indicative of a mantle reservoir that underwent long-term depletion of $\mathrm{Nd}$.

In addition, similar depletion ages (i.e. $1.2 \mathrm{Ga}$ ) occur in the New Zealand mantle rocks (see Scott et al., 2019).

These results are consistent with recent Re-Os studies on abyssal peridotites and mantle tectonites from ophiolitic sequences showing that the convecting mantle contains harzburgite domains that underwent depletion events much older than the age of peridotite processing under the ridge (e.g., Harvey et al., 2006).

In summary, the New Caledonia harzburgites show Re-Os systematics typical of depleted upper mantle, showing Early Paleozoic Os isotopic equilibration and evidence for ancient depletion events (>1.0 Ga). This multi-stage history led to the depleted nature of the harzburgites and possibly resulted in their complex HSE geochemical signatures.

\section{Summary and conclusions}

A Re-Os isotopes, highly siderophile and chalcophile element investigation of the New Caledonia peridotites was carried out to unravel the behaviour of the aforementioned elements in lherzolites and harzburgites from the New Caledonia ophiolite.

The lherzolites exhibit subchondritic to slightly suprachondritic ${ }^{187} \mathrm{Os} /{ }^{188} \mathrm{Os}_{\mathrm{i}}(0.1273-0.1329)$. PM-normalised HSE abundance diagrams are characterised by gently sloping patterns showing increasing depletion towards $\mathrm{Re}-\mathrm{Au}$, similar to lherzolites that experienced low to moderate melt extraction. However, the lack of correlation between HSE and fertility indicators, as well as the slightly suprachondritic Os isotopic ratios, argue against a simple partial melting history. Rather, such features and the presence of included and interstitial residual monosulphides possibly indicate that melting involved a mantle domain that has previously experienced a melt percolation event. The high S concentrations of the lherzolites (202-1268 ppm) most likely resulted from late-stage seawater-rock reactions.

By contrast, the New Caledonia harzburgites record higher degrees of melt extraction, as attested by the strikingly low, often below the detection limit, concentrations of incompatible chalcophile elements. Despite their homogeneity in terms of mineralogical and major element compositions, HSE patterns and Os isotopic compositions indicate the occurrence of two distinct harzburgite sub-groups.

Type-A harzburgites are characterised by steeply plunging HSE patterns, showing IPGE-PPGE and Os-Ir-Ru fractionation, coupled with low $\mathrm{Re} / \mathrm{Os}$ ratios and subchondritic ${ }^{187} \mathrm{Os} /{ }^{188} \mathrm{Os}$. The strongly fractionated HSE patterns and the positive Pt anomalies, together with the high modelled melting degrees, indicate that melting occurred under hydrous conditions in sub-arc mantle.

Type-B harzburgites display notably different HSE patterns, showing depleted Os-Ir compared to Ru, positive anomalies and Pd-Re reenrichments (relative to IPGE), coupled with chondritic to strongly suprachondritic measured Os isotopic ratios $\left({ }^{187} \mathrm{Os} /{ }^{188} \mathrm{Os}=\right.$ $0.127-0.153)$. These features have not been yet identified in mantle tectonites.

The similar and slightly oxidising oxygen fugacity values recorded by the two sub-types, named type-A and B, do not convincingly support the hypothesis that type-B patterns could be ascribed to massive interactions with an oxidising agent. By contrast, this observation, coupled with the uniform mineralogical and geochemical characters of the New Caledonia harzburgites, suggest that type-B patterns were not the result of a specific depletion or enrichment process related to their recent tectonic evolution in a subduction setting. Rather, these patterns could reflect the occurrence of a geochemically heterogeneous mantle source below the New Caledonia archipelago, similar to what was speculated for the New Zealand mantle. The HSE 
signature carried by the studied peridotites, as well as the puzzling similarity observed between the New Caledonia harzburgites and the New Zealand mantle xenoliths, might attest the presence of a mantle source bearing a long lasting evolution $(>1 \mathrm{Ga})$, possibly linked to the Zealandia formation.

\section{Declaration of Competing Interest}

The authors declare that they have no known competing financial interests or personal relationships that could have appeared to influence the work reported in this paper.

\section{Acknowledgements}

The authors are grateful to M. Feth and D. Cluzel for help and support during clean laboratory work and sampling in New Caledonia, respectively. A.G. wishes to thank Russian Science Foundation project 17-7710103 for supporting iron oxidation state investigations at Freie Universität of Berlin. We are indebted to Nadia Malaspina and Tiziano Catelani (University of Milano Bicocca) for providing access to SEMEDS analyses of sulphides.

We also thank C. Bonadiman and A. Woodland for editorial handling. Constructive reviews by two anonimous reviewers are gratefully acknowledged.

This study represents a continuation of the PhD project of A.S. on the New Caledonia ophiolite, that has been supported by DFG funding, Germany (SFB-TRR 170 Subproject B2) and Italian-PRIN prot. 2015C5LN35. This work has also benefited from the equipment and framework of the COMP-HUB Initiative, funded by the 'Departments of Excellence' program of the Italian Ministry for Education, University and Research (MIUR, 2018-2022). This is TRR 170 publication no. 86.

\section{References}

Ackerman, L., Walker, R.J., Puchtel, I.S., Pitcher, L., Jelínek, E., Strnad, L., 2009. Effects of melt percolation on highly siderophile elements and Os isotopes in subcontinental lithospheric mantle: a study of the upper mantle profile beneath Central Europe. Geochim Cosmochim. Acta 73, 2400-2414.

Aitchison, J.C., Clarke, L., Meffre, S., Cluzel, D., 1995. Eocene arc-continent collision in New Caledonia and implications for regional Southwest Pacific tectonic evolution. Geology 23, 161-164.

Alard, O., Griffin, W.L., Lorand, J.P., Jackson, S.E., O'Really, S.Y., 2000. Non-chondritic distribution of the highly siderophile elements in mantle sulphides. Nature 407, 891-894.

Alard, O., Griffin, W.L., Pearson, N.L., Lorand, J.-P., O’Really, S.Y., 2002. New insights into the Re-Os systematics of sub-continental lithospheric mantle from in situ analysis of sulfides. Earth Planet. Sci. Lett. 203, 651-663.

Alard, O., Luguet, A., Pearson, N.J., Griffin, W.L., Lorand, J.P., Gannoun, A., Burton, K.W., O'Reilly, S.Y., 2005. In situ Os isotopes in abyssal peridotites bridge the isotopic gap between MORBs and their source mantle. Nature 436, 1005-1008.

Alt, J.C., Shanks, W.C., 1998. Sulfur in serpentinized oceanic peridotites: Serpentinization processes and microbial sulfate reduction. J. Geophys. Res. 103, 9917-9929.

Alt, J.C. Shanks, W.C. 2003. Serpentinization of abyssal peridotites from the MARK area Mid-Atlantic Ridge: Sulfur geochemistry and reaction modeling. Geochim. Cosmochim. Acta 67, 641-653.

Andrews, D.R.A., Brenan, J.M., 2002. Phase-equilibrium constraints on the magmatic origin of laurite + Ru-Os-Ir alloy. Can. Mineral. 40, 1705-1716.

Becker, H., Dale, C., 2016. Re-Pt-Os isotopic and highly siderophile element behavior in oceanic and continental mantle tectonites. Rev. Mineral. Geochem. 369-440.

Becker, H., Horan, M.F., Walker, R.J., Gao, S., Lorand, J.P., Rudnick, R.L., 2006. Highly siderophile element composition of the Earth 's primitive upper mantle : Constraints from new data on peridotite massifs and xenoliths. Geochim. Cosmochim. Acta 70, $4528-4550$.

Birck, J.L., Barman, M.R., Capmas, F., 1997. Re-Os Isotopic Measurements at the Femtomole Level in Natural Samples. Geostand. Geoanal. Res. 21, 19-27.

Birner, S.K., Warren, J.M., Cottrell, E., Davis, F.A., Kelley, K.A., Falloon, T.J., 2017. Forearc peridotites from Tonga record heterogeneous oxidation of the mantle following subduction initiation. J. Petrol. 58 (9), 1755-1780.

Brandon, A.D., Draper, D.S., 1996. Constraints on the origin of the oxidation state of mantle overlying subduction zones: an example from Simcoe, Washington, USA Geochimica et Cosmochica Acta 60, 1739-1749.

Brandon, A.D., Creaser, R.A., Shirey, S.B., Carlson, R.W., 1996. Osmium recycling in subduction zones. Science 272, 861-864.
Brandon, A.D., Norman, M.D., Walker, R.J., Morgan, J.W., 1999. 1860s-1870s systematics of Hawaiian picrites. Earth Planet. Sci. Lett. 174, 25-42.

Brandon, A.D., Snow, J.E., Walker, R.J., Morgan, J.W., Mock, T.D., 2000. 190Pt-1860s and 187Re-1870s systematics of abyssal peridotites. Earth Planet. Sci. Lett. 177, 319-335.

Brenan, J.M., Andrews, D., 2001. High-temperature stability of laurite and Ru Os Ir alloy and their role in PGE fractionation in mafic magmas. Can. Mineral. 39, 341-360.

Brenan, J.M., Bennett, N.R., Zajacz, Z., 2016. Experimental results on fractionation of the highly siderophile elements (HSE) at variable pressures and temperatures during planetary and magmatic differentiation. Rev. Mineral. Geochem. 81, 1-87.

Bryndzia, L.T., Wood, B.J., 1990. Oxygen thermobarometry of abyssal spinel peridotites; the redox state and $\mathrm{C}-\mathrm{O}-\mathrm{H}$ volatile composition of the Earth's sub-oceanic upper mantle. Am. J. Sci. 290, 1093-1116.

Büchl, A., Brügmann, G., Batanova, V.G., Münker, C., Hofmann, A.W., 2002. Melt percolation monitored by Os isotopes and HSE abundances: a case study from the mantle section of the Troodos Ophiolite. Earth Planet. Sci. Lett. 204, 385-402.

Büchl, A., Brügmann, G.E., Batanova, V.G., Hofmann, A.W., 2004. Os mobilization during melt percolation: the evolution of Os isotope heterogeneities in the mantle sequence of the Troodos ophiolite, Cyprus. Geochim. Cosmochim. Acta 68, 3397-3408.

Bulanova, G.P., Griffin, W.L., Ryan, C.G., Shestakova, O.Y., Barnes, S.-J., 1996. Trace elements in sulfide inclusions from Yakutian diamonds. Contrib. Mineral. Petrol. 124, 111-125.

Cluzel, D., Aitchison, J.C., Picard, C., 2001. Tectonic accretion and underplating of mafic terranes in the late Eocene intraoceanic fore-arc of New Caledonia (Southwest Pacific): geodynamic implications. Tectonophysics 340, 23-59.

Cluzel, D., Meffre, S., Maurizot, P., Crawford, A.J., 2006. Earliest Eocene (53 Ma) convergence in the Southwest Pacific; evidence from pre- obduction dikes in the ophiolite of New Caledonia. Terra Nova 18, 395-402.

Cluzel, D., Maurizot, P., Collot, J., Sevin, B., 2012. An outline of the Geology of New Caledonia; from Permian - Mesozoic Southeast Gondwanaland active margin to Cenozoic obduction and supergene evolution. Episodes 35, 72-86.

Cluzel, D., Ulrich, M., Jourdan, F., Meffre, S., Paquette, J.L., Audet, M.A., Secchiari, A., Maurizot, P., 2016. Early Eocene clinoenstatite boninite and boninite-series dikes of the ophiolite of New Caledonia; a witness of slab-derived enrichment of the mantle wedge in a nascent volcanic arc. Lithos 260, 429-442.

Cohen, A.S., Waters, F.G., 1996. Separation of osmium from geological materials by solvent extraction for analysis by thermal ionisation mass spectrometry. Anal. Chim. Acta 332, 269-275.

Dale, C.W., Burton, K.W., Pearson, D.G., Gannoun, A., Alard, O., Argles, T.W., Parkinson, I.J. 2009. Highly siderophile element behaviour accompanying subduction of oceanic crust : whole rock and mineral-scale insights from a high-pressure terrain. Geochim. Cosmochim. Acta 73, 1394-1416.

Debret, B., Andreani, M., Delacour, A., Rouméjon, S., Trcera, N., EIMF, Williams, H., 2017 Assessing sulfur redox state and distribution in abyssal serpentinites using XANES spectroscopy. Earth and Planetary Science Letters 466, 1-11.

Fischer-Gödde, M., Becker, H., Wombacher, F., 2011. Rhodium, gold and other highly siderophile elements in orogenic peridotites and peridotite xenoliths. Chem. Geol. 280, 365-383.

Fonseca, R.O.C., Mallmann, G., O'Neill, H., Campbell, I.H., 2007. How chalcophile is rhenium? An experimental study of the solubility of Re in sulphide mattes. Earth Planet. Sci. Lett. 260, 537-548.

Fonseca, R.O.C., Mallmann, G., O'Neill, H.S., Campbell, I.H., Laurenz, V., 2011. Solubility of Os and Ir in sulfide melt: Implications for Re/Os fractionation during mantle melting. Earth Planet. Sci. Lett. 311, 339-350.

Fonseca, R.O.C., Laurenz, V., Mallmann, G., Luguet, A., Hoehne, N., Jochum, K.P., 2012. New constraints on the genesis and long-term stability of Os-rich alloys in the the Earth's mantle. Geochim. Cosmochim. Acta 87, 227-242.

Foustoukos, D.I., Bizimis, M., Frisby, C., Shirey, S.B., 2015. Redox controls on Ni-Fe-PGE mineralization and $\mathrm{Re} / \mathrm{Os}$ fractionation during serpentinization of abyssal peridotite. Geochim. Cosmochim. Acta 150, 11-25.

Goncharov, A., 2018. In-situ iron oxidation state in the upper mantle minerals using electron microprobe. Contributions to 3rd European mantle workshop. Plinius 44, 172. https://doi.org/10.19276/plinius.2018.03015.

Goncharov, A.G. Ionov, D. A, 2012. Redox state of deep off-craton lithospheric mantle: New data from garnet and spinel peridotites from Vitim, southern Siberia. Contrib. Mineral. Petrol. 164 (5), 731-745.

Goncharov, A.G., Nikitina, L.P., Borovkov, N.V., Babushkina, M.S., Sirotkin, A.N., 2015. Thermal and redox equilibrium conditions of the upper-mantle xenoliths from the Quaternary volcanoes of NW Spitsbergen, Svalbard Archipelago. Russian Geology and Geophysics 56 (11), 1578-1602.

Guo, J., Griffin, W.L., O’Reilly, S.Y., 1999. Geochemistry and origin of sulphide minerals in mantle xenoliths: Qilin, Southeastern China. J. Petrol. 40, 1125-1149.

Harvey, J., Gannoun, A., Burton, K.W., Rogers, N.W., Alard, O., Parkinson, I.J., 2006. Ancient melt extraction from the oceanic upper mantle revealed by Re-Os isotopes in abyssal peridotites from the Mid-Atlantic ridge. Earth Planet. Sci. Lett. 244, 606-621.

Hattori, K.H., Arai, S., Clarke Barrie, D.B., 2002. Selenium, tellurium, arsenic and antimony contents of primary mantle sulfides. Can. Mineral. 40, 637-650.

Helmy, H.M., Ballhaus, C., Wohlgemuth-Ueberwasser, C., Fonseca, R.O.C., Laurenz, V. 2010. Partitioning of Se, as, Sb, Te and Bi between monosulfide solid solution and sulfide melt - Application to magmatic sulfide deposits. Geochim. Cosmochim. Acta 74, 6174-6179.

Höfer, H.E., Brey, G.P., 2007. The iron oxidation state of garnet by electron microprobe: its determination with the flank method combined with major-element analysis. Am. Mineral. 92, 873-885.

Kepezhinskas, P., Defant, M.J., Widom, E., 2002. Abundance and distribution of PGE and au in the island-arc mantle: implications for sub-arc metasomatism. Lithos 60, 113-128. 
Klein, F., Bach, W., 2009. Fe-Ni-Co-O-S phase Relations in Peridotite-Seawater Interactions. J. Petrol. 50, 37-59.

Lagabrielle, Y., Chauvet, A., Ulrich, M., Guillot, S., 2013. Passive obduction and gravitydriven emplacement of large ophiolitic sheets: the New Caledonia ophiolite (SW Pacific) as a case study? Bulletin de la Société Géologique de France 184, 545-556.

Lassiter, J.C., Byerly, B.L., Snow, J.E., Hellebrand, E., 2014. Constraints from Os-isotope variations on the origin of Lena Trough abyssal peridotites and implications for the composition and evolution of the depleted upper mantle. Earth Planet. Sci. Lett. 403, $178-187$.

Liu, C., Snow, J.E., Brügmann, G., Hellebrand, E., Hofmann, A.W., 2009. Non-chondritic HSE budget in Earth's upper mantle evidenced by abyssal peridotites from Gakkel ridge (Arctic Ocean). Earth Planet. Sci. Lett. 283, 122-132.

Li, J., Kornprobst, J., Vielzeuf, D., Fabriès, J., 1995. An improved experimental calibration of the olivine-spinel geothermometer. Chin. J. Geochem. 14, 68-77.

Liu, J., Scott, J.M., Martin, C.E., Pearson, D.G., 2015. The longevity of Archean mantle residues in the convecting upper mantle and their role in young continent formation. Earth Planet. Sci. Lett. 424, 109-118.

Lorand, J.P., Alard, O., 2010. Determination of selenium and tellurium concentrations in Pyrenean peridotites (Ariege, France): New insight into S/Se/Te systematics of the upper in mantle samples. Chem. Geol. 278, 120-130.

Lorand, J.-P., Pattou, L., Gros, M., 1999. Fractionation of platinum-group elements and gold in the upper mantle: a detailed study in pyrenean orogenic lherzolites. J. Petrol. 40, 957-981.

Lorand, J.P., Alard, O., Luguet, A., Keays, R.R., 2003. Sulfur and selenium systematics of the subcontinental lithospheric mantle: Inferences from the Massif Central xenolith suite (France). Geochim. Cosmochim. Acta 67, 4137-4151.

Lorand, J.P., Delpech, G., Grégoire, M., Moine, B., O’Reilly, S.Y., Cottin, J.Y., 2004. Platinumgroup elements and the multistage metasomatic history of Kerguelen lithospheric mantle (South Indian Ocean). Chem. Geol. 208, 195-215.

Lorand, J., Luguet, A., Alard, O., 2008. Platinum-group elements : a new set of key tracers for the Earth's interior. Elements 4, 247-252.

Luguet, A., Alard, O., Lorand, J.P., Pearson, N.J., Ryan, C.Y., Reilly, S.Y.O., 2001. Laser-ablation microprobe (LAM) -ICPMS unravels the highly siderophile element geochemistry of the oceanic mantle. Earth Planet. Sci. Lett. 189, 285-294.

Luguet, A., Lorand, J.P., Seyler, M., 2003. Sulfide petrology and highly siderophile element geochemistry of abyssal peridotites: a coupled study of samples from the Kane Fracture Zone ( $45^{\circ} \mathrm{W} 23^{\circ} 20 \mathrm{~N}$, MARK Area Atlantic Ocean). Geochim. Cosmochim. Acta $67,1553-1570$.

Luguet, A., Lorand, J., Alard, O., Cottin, J., 2004. A multi-technique study of platinum group element systematic in some Ligurian ophiolitic peridotites, Italy. Chem. Geol. 208, 175-194.

Luguet, A., Shirey, S.B., Lorand, J.P., Horan, M.F., Carlson, R.W., 2007. Residual platinumgroup minerals from highly depleted harzburgites of the Lherz massif (France) and their role in HSE fractionation of the mantle. Geochim. Cosmochim. Acta 71, 3082-3097.

Marchesi, C., Garrido, C.J., Godard, M., Belley, F., Ferré, E., 2009. Migration and accumulation of ultra-depleted subduction-related melts in the Massif du Sud ophiolite (New Caledonia). Chem. Geol. 266, 171-186.

Marchesi, C., Garrido, C.J., Harvey, J., 2013. Platinum-group elements, S, Se and Cu in highly depleted abyssal peridotites from the Mid-Atlantic Ocean Ridge (ODP Hole $1274 \mathrm{~A})$ : Influence of hydrothermal and magmatic processes. Contrib. Mineral. Petrol. $166,1521-1538$.

Mathez, E.A., 1976. Sulfur solubility and magmatic sulfides in submarine basalt glass. J. Geophys. Res. 81, 4269-4276.

McInnes, B.I.A., McBride, J.S., Evans, N.J., Lambert, D.D., Andrew, A.S., 1999. Osmium isotope constraints on ore metal recycling in subduction zones. Science 286 , 512-516.

Meisel, T., Walker, R.J., Morgan, J.V., 1996. The osmium isotopic composition of the Earth's primitive upper mantle. Nature $383,517-520$

Meisel, T., Walker, R.J., Irving, A.J., Lorand, J.-P., 2001. Osmium isotopic compositions of mantle xenoliths: a global perspective. Geochim. Cosmochim. Acta 65, 1311-1323.

Mungall, J.E., Brenan, J., 2014. Partitioning of platinum-group elements and Au between sulfide liquid and basalt and the origins of mantle-crust fractionation of the chalcophile elements. Geochim. Cosmochim. Acta 125, 265-289.

Nier, A.O., 1950. A redetermination of the relative abundances of the isotopes of carbon, nitrogen, oxygen, argon and potassium. Phys. Rev. B77, 789-793.

O'Driscoll, B., Day, J.M.D., Walker, R.J., Daly, J.S., McDonough, W.F., Piccoli, P.M., 2012. Chemical heterogeneity in the upper mantle recorded by peridotites and chromitites from the Shetland Ophiolite Complex, Scotland. Earth Planet. Sci. Lett. 333-334, 226-237.

Pagé, P., Barnes, S.-J., 2016. The influence of chromite on osmium, iridium, ruthenium and rhodium distribution during early magmatic processes. Chem. Geol. 420, 51-68.

Park, J., Campbell, I.H., Arculus, R.J., 2013. Platinum-alloy and sulfur saturation in an arcrelated basalt to rhyolite suite: evidence from the Pual Ridge lavas, the Eastern Manus Basin. Geochim. Cosmochim. Acta 101, 76-95.

Parkinson, I.J., Pearce, J.A., 1998. Peridotites from the Izu-Bonin-Mariana Forearc (ODP Leg 125): evidence for mantle melting and melt-mantle interaction in a suprasubduction zone setting. J. Petrol. (9), 1577-1618.
Parkinson, IJ. Arculus, R.J. 1999. The redox state of subduction zones: Insights from arcperidotites. Chem. Geol. 160, 409-423.

Parkinson, I.J., Arculus, R.J., Eggins, S.M., 2003. Peridotite xenoliths from Grenada, Lesser Antilles Island Arc. Contrib. Mineral. Petrol. 146, 241-262.

Pearson, D.G., Irvine, G.J., Ionov, D.A., Boyd, F.R., Dreibus, G.E., 2004. Re-Os isotope systematics and platinum group element fractionation during mantle melt extraction: study of massif and xenolith peridotite suites. Chem. Geol. 208, 29-59.

Pirard, C., Hermann, J., O'Neill, H., 2013. Petrology and geochemistry of the crust- mantle boundary in a nascent arc, Massif du Sud ophiolite, New Caledonia, SW Pacific. Journal of Petrology 0,1-34.

Rehkämper, M., Halliday, A.N., Alt, J., Fitton, J.G., Zipfel, J., Takazawa, E., 1999. Nonchondritic platinum-group element ratios in oceanic mantle lithosphere: petrogenetic signature of melt percolation? Earth Planet. Sci. Lett. 172, 65-81.

Reisberg, L., Lorand, J.-P., 1995. Longevity of sub-continental mantle lithosphere from osmium isotope systematics in orogenic peridotite massifs. Nature 376, 159-162.

Saha, A., Basu, A.R., Jacobsen, S.B., Poreda, R.J., 2005. Slab devolatilization and Os and Pb mobility in the mantle wedge of the Kamchatka arc. Earth Planet. Sci. Lett. 236, 182-194.

Salters, V.J.M., Stracke, A., 2004. Composition of the depleted mantle. Geochemistry Geophysics Geosystems 5 (5).

Scott, J.M., Liu, J., Pearson, D.G., Waight, T.E., 2016. Mantle depletion and metasomatism recorded in orthopyroxene in highly depleted peridotites. Chem. Geol. 441, 280-291.

Scott, J.M., Liu, J., Pearson, D.G., Harris, G.A., Czertowicz, T.A., Woodland, S.J., Riches, A.J.V Luth, R.W., 2019. Continent stabilisation by lateral accretion of subduction zoneprocessed depleted mantle residues; insights from Zealandia. Earth Planet. Sci. Lett. 507, 175-186.

Secchiari, A., 2016. Sr-Nd-Pb Isotope Investigation of the New Caledonia Ophiolite. PhD thesis. Parma and Montpellier University (191 pp).

Secchiari, A., Montanini, A., Bosch, D., Macera, P., Cluzel, D., 2016. Melt extraction and enrichment processes in the New Caledonia lherzolites: evidence from geochemical and Sr-Nd isotope data. Lithos 260, 28-43.

Secchiari, A., Montanini, A., Bosch, D., Macera, P., Cluzel, D., 2018. The contrasting geochemical message from the New Caledonia gabbronorites: insights on depletion and contamination processes of the sub-arc mantle in a nascent arc setting. Contrib. Mineral. Petrol. 173, 66.

Secchiari, A., Montanini, A., Bosch, D., Macera, P., Cluzel, D., 2019. Origin of the spinelpyroxene symplectites in the harzburgites from the New Caledonia peridotite. Ofioliti $44,31-42$.

Secchiari, A., Montanini, A., Bosch, D., Macera, P., Cluzel, D., 2020. Sr-Nd-Pb and trace element systematics of the New Caledonia harzburgites: tracking source depletion and contamination processes in a SSZ setting. In press on Geoscience Frontiers, special issue Ophiolites. https://doi.org/10.1016/j.gsf.2019.04.004.

Snow, J.E., Reisberg, L., 1995. Os isotopic systematics of the MORB mantle: results from altered abyssal peridotites. Earth Planet. Sci. Lett. 133, 411-421.

Snow, E.J., Schmidt, G., 1998. Constraints on the Earth accretion deduced from noble metals in the oceanic mantle. Nature 391, 166-169.

Snow, J., Schmidt, G., Rampone, E., 2000. Os isotopes and highly siderophile elements (HSE) in the Ligurian ophiolites, Italy. Earth Planet. Sci. Lett. 175, 119-132.

Standish, J.J., Hart, S.R., Blusztajn, J., Dick, H.J.B., Lee, K.L., 2002. Abyssal peridotite osmium isotopic compositions from Cr-spinel. Geochemistry Geophysics Geosystems 3 (1).

Ulmer, P., 2001. Partial melting in the mantle wedge - the role of $\mathrm{H} 2 \mathrm{O}$ in the genesis of mantle-derived 'arc-related' magmas. Phys. Earth Planet. In. 127, 215-232.

Ulrich, M., Picard, C., Guillot, S., Chauvel, C., Cluzel, D., Meffre, S., 2010. Multiple melting stages and refertilization as indicators for ridge to subduction formation: the New Caledonia ophiolite. Lithos 115, 223-236.

Walker, R.J., Hanski, E., Vuollo, J., Liipo, J., 1996. The Os isotopic composition of Proterozoic upper mantle: evidence for chondritic upper mantle from the Outokumpu ophiolite, Finland. Earth Planet. Sci. Lett. 141, 161-173.

Walker, R.J., Horan, M.F., Morgan, J.W., Becker, H., Grossman, J.N., 2002. Comparative 187Re-1870s systematics of chondrites: implications regarding early solar system processes. Geochim. Cosmochim. Acta 66, 4187-4201.

Wang, Z., Becker, H., 2013. Ratios of S, Se and Te in the silicate Earth require a volatile-rich late veneer. Nature 499, 328-331.

Wang, Z., Becker, H., Gawronski, T., 2013. Partial re-equilibration of highly siderophile elements and the chalcogens in the mantle : a case study on the Baldissero and Balmuccia. Geochim. Cosmochim. Acta 108, 21-44.

Whattam, S.A., 2009. Arc-continent collisional orogenesis in the SW Pacific and the nature, source and correlation of emplaced ophiolitic nappe components. Lithos 113 , 88-114.

Widom, E., 2011. Recognizing recycled Osmium. Geology 39, 1087-1088.

Widom, E., Kepezhinskas, P., Defant, M., 2003. The nature of metasomatism in the sub-arc mantle wedge: evidence from Re-Os isotopes in Kamchatka peridotite xenoliths. Chem. Geol. 196, 283-306.

Wood, B.J., Virgo, D., 1989. Upper mantle oxidation state: ferric iron contents of lherzolite spinels by $57 \mathrm{Fe}$ Mössbauer spectroscopy and resultant oxygen fugacities. Geochim. Cosmochim. Acta 53, 1277-1291.

Woodland, A.B., Kornprobst, J., Tabit, A., 2006. Ferric iron in orogenic lherzolite massifs and controls of oxygen fugacity in the upper mantle. Lithos 89, 222-241. 